\title{
Discrimination of Tilletia controversa from the T. caries/T. laevis complex by MALDI-TOF MS analysis of teliospores
}

\author{
Monika K. Forster ${ }^{1,2} \cdot$ Somayyeh Sedaghatjoo ${ }^{3,4} \cdot$ Wolfgang Maier $^{3} \cdot$ Berta Killermann $^{1} \cdot$ Ludwig Niessen $^{2} \mathbb{D}$
}

Received: 19 July 2021 / Revised: 21 December 2021 / Accepted: 27 December 2021 / Published online: 17 January 2022

(c) The Author(s) 2022

\begin{abstract}
The fungal genus Tilletia includes a large number of plant pathogens of Poaceae. Only a few of those cause bunt of wheat, but these species can lead to significant yield losses in crop production worldwide. Due to quarantine regulations and specific disease control using appropriate seed treatments for the different disease agents, it is of high importance to distinguish Tilletia caries and Tilletia laevis as causal agents of common bunt accurately from Tilletia controversa, the causal agent of the dwarf bunt. Several studies have shown that matrix-assisted laser desorption/ionization-time of flight mass spectrometry (MALDI-TOF MS) is a useful tool to differentiate closely related fungal species. The aim of this study was to assess whether MALDI-TOF MS analysis is able to distinguish specimens of the three closely related pathogens T. caries, T. laevis, and T. controversa and whether it may constitute an alternative method to the morphology-based identification or germination tests. Spectral data are available via ProteomeXchange with identifier PXD030401. Spectra-based hierarchical cluster analysis (HCA) and discriminant analysis of principal components (DAPC) of the obtained mass spectra showed two main clusters. One cluster included specimens of T. controversa, whereas the second cluster comprised T. laevis and T. caries specimens. Even though main spectral profiles (MSPs) for species identification are missing, MALDI-TOF MS has proven to be a useful method for distinguishing between $T$. controversa and the two causal agents of common bunt, using direct analysis of teliospores, but was unable to separate T. caries and T. laevis species.
\end{abstract}

Key points

- MALDI-TOF MS was developed to classify Tilletia species causing bunt of wheat.

- Best results were achieved when combining HCA and DAPC analysis.

- The method resulted in an accuracy of $98.51 \%$ testing 67 Tilletia specimens.

Keywords Mass spectrometry $\cdot$ Spectral analysis $\cdot$ Common bunt $\cdot$ Dwarf bunt $\cdot$ Morphology $\cdot$ Germination

Ludwig Niessen

ludwig.niessen@tum.de

1 Institute for Crop Science and Plant Breeding, Bavarian State Research Center for Agriculture (LfL), Voettinger Str. 38, 85354 Freising, Germany

2 Chair of Microbiology, TUM School of Life Sciences, Technical University of Munich, Gregor-Mendel-Str. 4, 85354 Freising, Germany

3 Julius Kühn Institute (JKI) - Federal Research Centre for Cultivated Plants, Institute for Epidemiology and Pathogen Diagnostics, Messeweg 11-12, 38104 Braunschweig, Germany

4 Molecular Phytopathology and Mycotoxin Research, University of Goettingen, Grisebachstrasse 6, 37077 Goettingen, Germany

\section{Introduction}

More than 170 Tilletia species (Tilletiales, Exobasidiomycetes, Ustilaginomycotina) are described and distributed worldwide (Vánky 2012). All species parasitize on inflorescences or leaves of grasses (Poaceae). Species are highly diverse in terms of morphology and host specificity. The greater part of them has no economic impact, but a few Tilletia species infect economically important cereal crops causing severe yield losses or decreasing the capabilities for further processing due to the production of foul-smelling trimethylamine (Hanna et al. 1932). Wheat is affected by four Tilletia species, whereas the causal agents of common bunt of wheat, Tilletia caries (DC) Tul. (syn. T. tritici (Bjerk.) G. Winter) and Tilletia laevis Kühn (syn. T. foetida (Wallr.) Liro)), as well as wheat 
dwarf bunt, Tilletia controversa Kühn, are closely related species (Carris et al. 2007). Tilletia indica (Mitra), the causal agent of karnal bunt of wheat, is more distantly related (Jayawardena et al. 2019) and has a distinct and limited geographical distribution (Goates 1996). In most areas of the world, the two species $T$. indica and T. controversa are categorized as a quarantine pest (Peterson et al. 2009; IPPC 2016; EPPO 2021; https://gd.eppo.int/ taxon/TILLCO/categorization). Therefore, efficient and accurate identification methods to discriminate Tilletia species on wheat are essential with regard to the global trade of seeds and cereals as well as for targeted treatment of the pathogens.

Tilletia caries, T. laevis, and T. controversa are described as three distinct species, based on their morphological and physiological features (Goates 1996; Vánky 2012). Morphologically, the three Tilletia species are determined based on their teliospore characteristics (Hoffmann 1982; Goates 1996; Vánky 2012). However, the morphological distinction of teliospores is challenging because the properties frequently overlap and the morphological variability of the teliospores can be quite high (Holton and Kendrick 1956; Holton et al. 1968). It is important to use mature teliospores for the identification of the Tilletia species as morphology differs with teliospore age (Durán and Fischer 1961). Because of extensive variation in the morphological as well as in several physiological and genetic traits, it was also suggested that the three species might be conspecific (Russell and Mills 1994). Phylogenetic and phylogenomic studies could not resolve the three species, respectively (Carris et al. 2007; Sedaghatjoo et al. 2021b, submitted). The germination behavior of teliospores of $T$. caries, $T$. laevis, and $T$. controversa correlates with the disease symptoms they are causing. The causal agents of common bunt, $T$. caries and T. laevis, start to germinate at $14-16{ }^{\circ} \mathrm{C}$ within 4 to 5 days, but also germinate at $5{ }^{\circ} \mathrm{C}$, needing roughly double the time (Lowther 1950). By contrast, teliospores of $T$. controversa only germinate at $5{ }^{\circ} \mathrm{C}$ within 4 to 6 weeks (Meiners and Waldher 1959) and no germination occurs at higher temperatures. However, germination testing is unable to distinguish between $T$. caries and T. laevis, observation of the germination behavior of teliospores was found to be the most reliable approach to differentiate teliospores of common and dwarf bunt of wheat (Trione and Krygier 1977). Nevertheless, this classification method is very time-consuming and not applicable in official seed testing.

Several studies have attempted the detection of the wheat bunt species using PCR or other DNA-based methods. But, most of these assays are not able to distinguish between common (T. caries/T. leavis) and dwarf bunt ( $T$. controversa). In particular, none of the assays is able to differentiate the two common bunt taxa T. caries and T. laevis
(Mulholland and McEwan 2000; Josefsen and Christiansen 2002; Kochanová et al. 2004; Zouhar et al. 2010; Pieczul et al. 2018). Other assays designed to specifically detect $T$. controversa were only tested against a relatively small number of specimens but it was not shown if the specificity applies to a high number of specimens with different origins (Liu et al. 2009, 2020; Gao et al. 2010, 2011, 2014).

An approach that analyzed protein patterns of $T$. caries and T. controversa extracts with electrophoresis methods was applied to determine species-specific differences (Banowetz et al. 1984; Weber and Schauz 1985). Kawchuk et al. (1988) found 359 polypeptides that were common among $T$. caries, $T$. controversa, and T. laevis, but the authors were unable to correlate the remaining $13 \%$ of uncommon polypeptides with morphological or physiological properties of the three species. In another analysis, an abundant $116-\mathrm{kD}$ polypeptide of undefined nature was detected in extracts from teliospores of $T$. controversa exclusively (Banowetz and Doss 1994). Numerous research groups tried to develop immunoassays to differentiate the three Tilletia species, but were unable to create assays specific to all three of them (Eibel et al. 2005; Zhang et al. 2007; Gao et al. 2015). Innovative proteomic analyses of Tilletia species were performed by Li et al. (2018) using the isobaric tags for relative and absolute quantitation (iTRAQ) technique to explore proteomic differences among $T$. controversa, T. caries, and T. laevis by detecting relative quantities of specific proteins between the pathogens and Pandey et al. (2018 and 2019) applied tandem mass spectrometry to identify pathogenicity or virulence-related proteins of T. indica.

In several studies, matrix-assisted laser desorption/ ionization time-of-flight mass spectrometry (MALDI-TOF MS) analysis of fungal subproteomes was introduced as a useful and rapid tool to identify and classify microorganisms (Chalupová et al. 2014). This approach was originally used for bacterial identification (Welham et al. 1998). Li et al. (2000) and Welham et al. (2000) were the first to transfer the application from bacteria to spores of clinically relevant filamentous fungi. Increasing numbers of protocols have been published to analyze fungal spores by MALDI-TOF MS for a broad variety of fungi and oomycetes, including many phytopathogens (Böhmer et al. 2007; Kemptner et al. 2009; Sulc et al. 2009; Bhadauria et al. 2010; Brun et al. 2013; Beinhauer et al. 2016). The technique was also applied to distinguish closely related species (Gruenwald et al. 2015; Wigmann et al. 2019) and could therefore also be a useful tool for the discrimination of the wheat bunt fungi T. caries, T. laevis, and T. controversa. The purpose of the current study was to develop and test a protocol for the MALDI-TOF MS-based analysis of Tilletia spp. teliospores for a fast and reliable distinction of the bunt pathogens of wheat. 


\section{Material and methods}

\section{Tilletia teliospore material}

The 69 analyzed specimens of T. caries, T. laevis, T. controversa, and T. indica, their geographic origins, and voucher information are listed in Table 1. The infected spikelets and individual bunt balls of T. caries, T. laevis, and T. controversa originated mainly from Europe and the USA, while two specimens of $T$. controversa were originally collected in Turkey, but maintained through wheat infections in the USA (Goates 2012). The two T. indica specimens originated from India and Mexico. All specimens were stored as intact bunt balls, mainly in the ears of wheat, at $10{ }^{\circ} \mathrm{C}$ and weakly humid conditions at the official seed testing laboratory of the Bavarian State Research Center for Agriculture (LfL, Freising, Germany).

\section{Morphological determination of the bunt species}

For morphological identification of the species, teliospores of each specimen were isolated from intact bunt balls, embedded in Hoyer's fluid (Cunningham 1972), and determined using light microscopy considering the main differentiation criteria shape and degree of reticulation of the teliospores (ISTA 1984; Vánky 2012). The examination was performed independently by seven scientists, all experienced in the morphological determination of bunts of wheat.

\section{Classification by germination behavior and culture conditions}

To determine species group identification by germination behavior, two units of approximately hundreds of thousands to one million teliospores of all T. caries, T. laevis, and $T$. controversa specimens were surface sterilized using $0.26 \%$ aqueous solution of sodium hypochlorite and rinsed twice in sterile water (Wilcoxson and Saari 1996). Subsequently, the teliospores were resuspended in $500 \mu$ sterile water and streak inoculated on $2 \%$ water agar. Each specimen was incubated at $5{ }^{\circ} \mathrm{C}$ and $15{ }^{\circ} \mathrm{C}$, respectively, for up to 6 weeks. Samples were controlled daily under the light microscope to detect the starting time of germination and to calculate the germination rate. Following the definition of Schauz (1968), a Tilletia teliospore was judged as germinated when the hypha was at least as long as the diameter of the teliospore. This was repeated twice for each specimen.

Two specimens, $T$. caries (AL15) and T. controversa (OL16), were selected in this study to implement and optimize the method. A single germinated teliospore of these Tilletia specimens was transferred to M-19 agar media (Trione 1964) and cultivated, maintained, and lyophilized as described by Sedaghatjoo et al. (2021a) to obtain enough biomass for MALDI-TOF MS analyses. Lyophilized mycelium of specimens AL15 and OL16 were stored at the Federal Research Centre for Cultivated Plants (JKI, Braunschweig, Germany).

\section{Sample preparation for MALDI-TOF MS analysis}

Samples were prepared from teliospores and lyophilized mycelium. For teliospore isolation, bunt balls were opened carefully on weighing paper (Macherey-Nagel GmbH, Düren, Germany) using a pair of fine forceps. The wheat tissue was removed and the teliospores were transferred to a 2-ml reaction tube (Eppendorf, Hamburg, Germany). Three milligrams of lyophilized mycelia or teliospores, respectively, was transferred into a $1.5-\mathrm{ml}$ reaction tube (Eppendorf, Hamburg, Germany). Surface sterilization and inactivation of the fungal cells was performed by resuspending in $300 \mu \mathrm{l}$ sterile deionized water and subsequently applying $900 \mu \mathrm{l}$ of ethanol (VWR International, Fontenaysous-Bois, France). Samples were vortexed and centrifuged (Andreas Hettich $\mathrm{GmbH}$, Tuttlingen, Germany) for $10 \mathrm{~min}$ at $4{ }^{\circ} \mathrm{C}, 21,380 \times g$. The supernatant was carefully removed by pipetting and the pellet was dried completely in a laminar flow cabinet for $30 \mathrm{~min}$ (teliospores) or in a vacuum desiccator at 5 mbar (mycelium) with the lids of the reaction tubes open. Extraction of the proteins from the mycelium was performed according to the ethanol/formic acid extraction sample preparation protocol for microorganism (Bruker Daltonik GmbH 2011). The procedure was slightly modified to extract the proteins from teliospores. These were first suspended in $100 \mu \mathrm{l}$ of formic acid (70\%) (SigmaAldrich Chemie, Steinheim, Germany) and then transferred to innuSPEED Lysis Tube X (2 ml) (Analytik Jena, Jena, Germany) containing sterile ceramic beads of different sizes (0.4-0.6 mm \& 1.4-1.6 mm). Homogenization of the samples was conducted in a FastPrep®-24 (MP Biomedicals, Eschwege, Germany) at $6.0 \mathrm{~m} / \mathrm{s}$ for $40 \mathrm{~s}$. After the addition of $100 \mu \mathrm{l}$ of acetonitrile (100\%) (Sigma-Aldrich Chemie, Steinheim, Germany), samples were vortexed for $5 \mathrm{~min}$ at maximum speed. The suspension was transferred into a new 1.5-ml reaction tube without ceramic beads. Samples were centrifuged for $2 \mathrm{~min}$ at room temperature at $20,000 \times \mathrm{g}$. A MALDI 96 polished steel target plate (Bruker Daltonics, Bremen, Germany) was prepared by applying $1 \mu \mathrm{l}$ of matrix solution containing $10 \mathrm{mg} / \mathrm{ml} \alpha$-cyano-4-hydroxy-cinnamic acid in acetonitrile, deionized water, and trifluoroacetic acid (50:47.5:2.5, v/v/v) (Sigma-Aldrich Chemie, Steinheim, Germany). One microliter of the cell-free supernatant was transferred on top of the air-dried matrix spot, allowed to air dry at room temperature, and subsequently overlaid by another $1 \mu \mathrm{l}$ of matrix solution before being air-dried again 


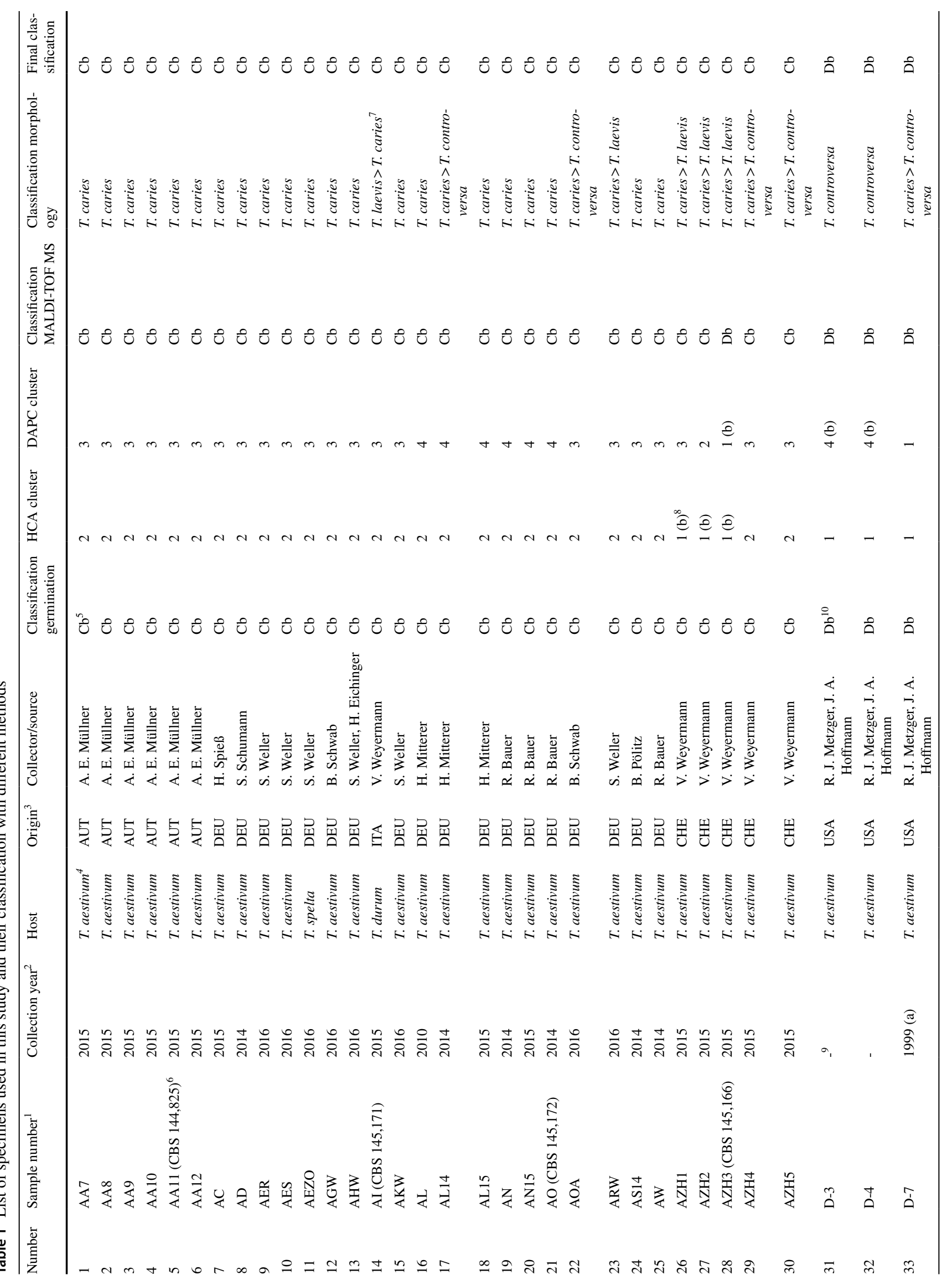




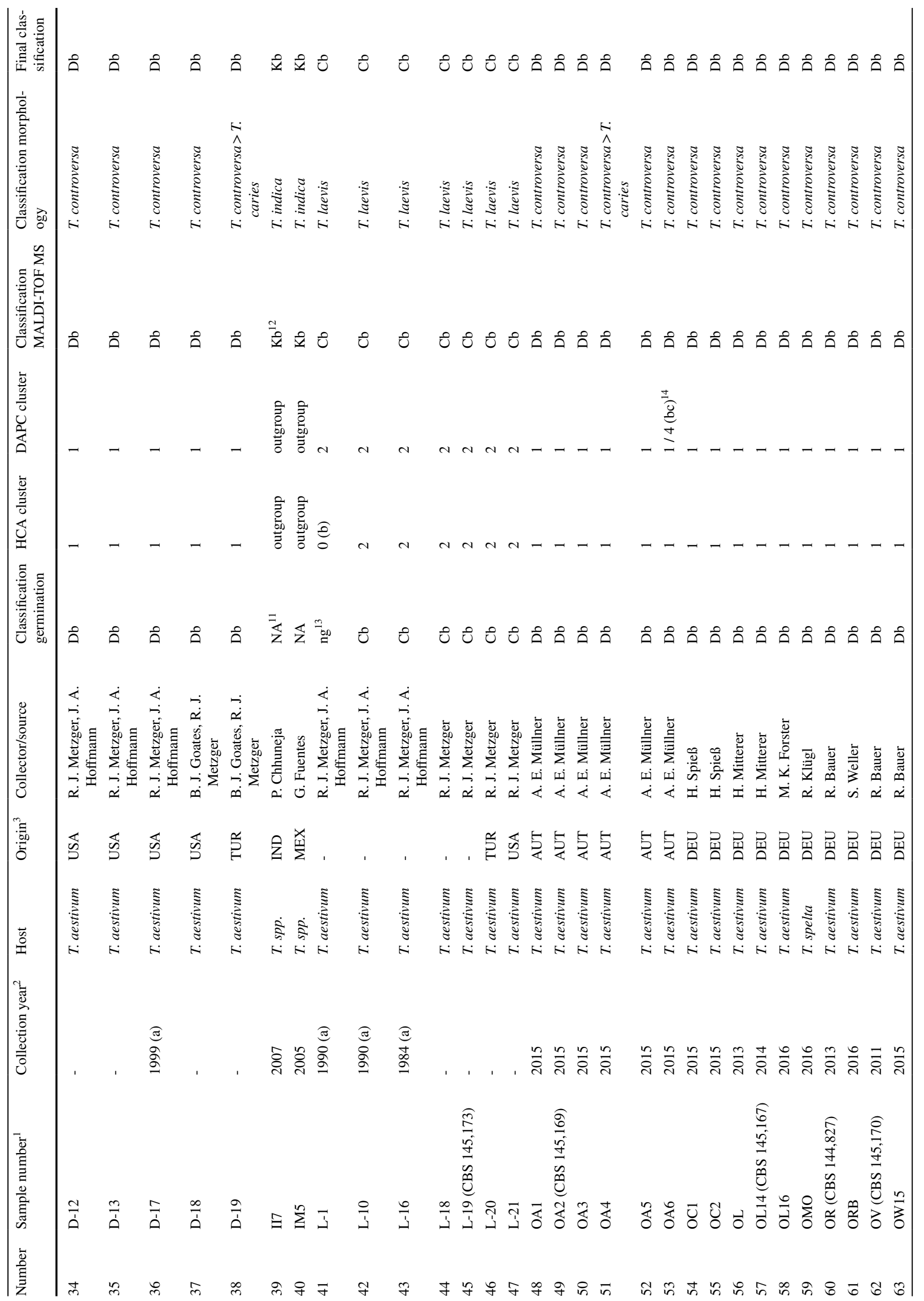




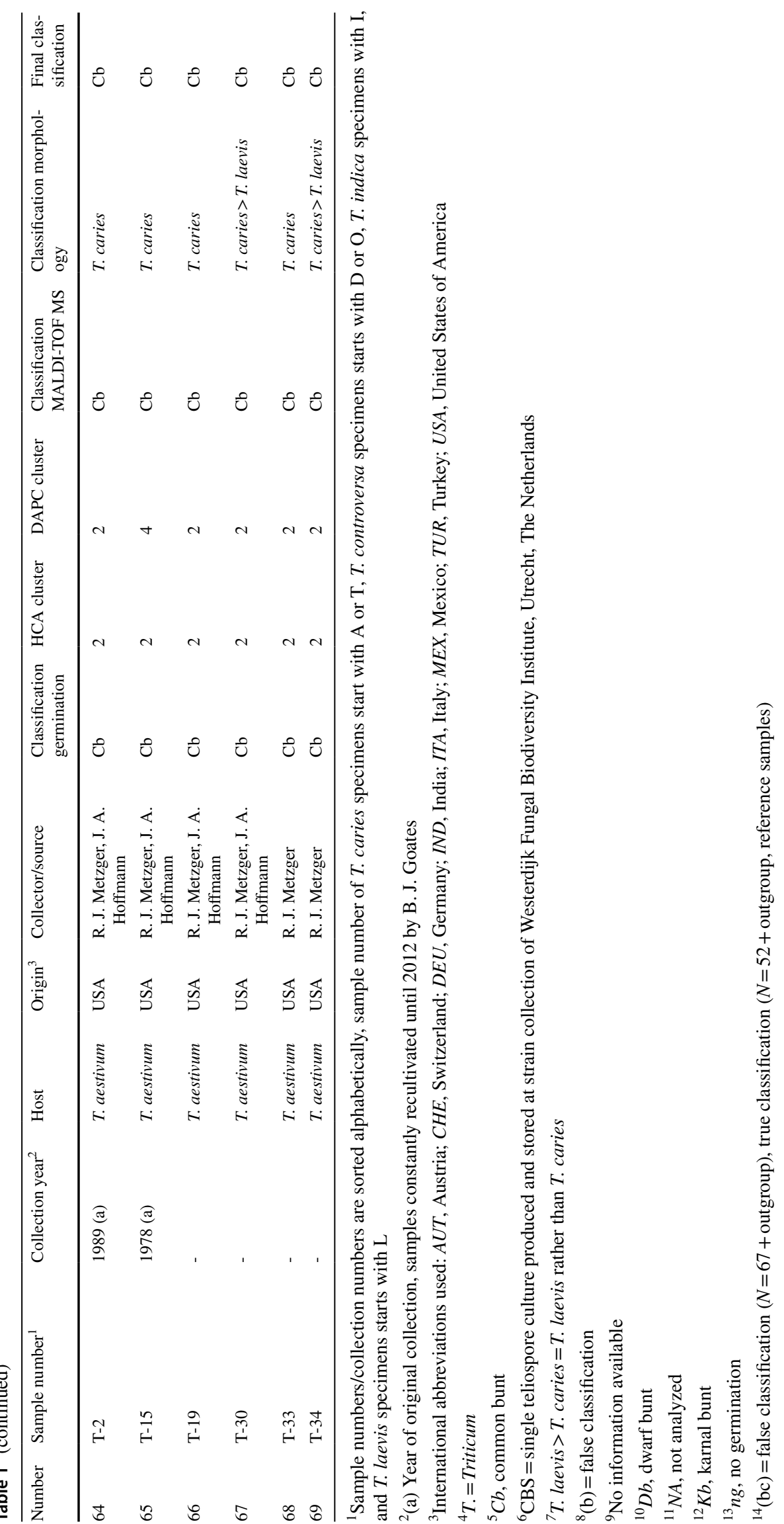


at ambient temperature. Three replicates of each sample were prepared and analyzed.

\section{MALDI-TOF mass spectra collection and data processing}

Mass spectra were generated using a Microflex LT MALDITOF mass spectrometer (Bruker Daltonics, Bremen, Germany) equipped with a nitrogen laser $(\lambda=337 \mathrm{~nm})$ recording spectra in linear positive ion detection mode at a laser frequency of $20 \mathrm{~Hz}$ within a mass range from 2000 to $20,000 \mathrm{Da}$. The software used for data acquisition was MALDI Biotyper 3.0 Realtime classification (RTC) (Bruker Daltonics, Bremen, Germany) and FlexControl 3.4 (Bruker Daltonics, Bremen, Germany). Parameter settings were $20.11 \mathrm{kV}$ (ion source 1), $18.86 \mathrm{kV}$ (ion source 2), $6.53 \mathrm{kV}$ (lens), and pulsed ion extraction $230 \mathrm{~ns}$. The laser power was adjusted to $40 \%$ with an attenuator range of $30 \%$ and an offset of 23\%. Each MALDI-TOF mass spectrum was recorded by 40 -shot steps from random positions of the target spot, summarized to 240 single spectra.

The software FlexAnalysis 3.4 (Bruker Daltonics, Bremen, Germany) was used for visual inspection of the recorded mass spectra. Raw data was converted to a text file, listing intensities versus $m / z$ data points spaced $0.25 \mathrm{Da}$ from each other. Preprocessing steps like subtracting the baseline, smoothing and normalizing signal intensities of the single mass spectra, peak picking, and the calculation of the signal to noise ratio (SNR) based on the noise level for each $\mathrm{m} / \mathrm{z}$ value were performed by using mass spectrometry comparative analysis package (MASCAP) (Mantini et al. 2010), implemented in the GNU Octave (3.8.1) software package (https://www.gnu.org/software/octave/), according to Schott et al. (2016). For further analysis and comparison, peaks of all extracted spectra were calibrated and aligned considering a tolerant peak shift range of $600 \mathrm{ppm}$ of the $\mathrm{m} / \mathrm{z}$ value to define peaks to be identical (Wang et al. 2006; Usbeck et al. 2014).

The reproducibility of the spectra extraction method was verified using MASCAP. Three biological replicates of each sample were spotted in triplicate onto the MALDI stainless polished steel target to obtain nine single spectra per specimen. These were summarized as one mean spectrum and illustrated in a stacked view. This visualization of MALDITOF MS spectra profiles was also used to compare the peak profiles of teliospores and mycelium of the reference specimens AL15 and OL16. The mass spectrometry proteomics data were deposited on the ProteomeXchange Consortium platform (http://proteomecentral.proteomexchange.org/cgi/ GetDataset) (Deutsch et al. 2020) via the PRIDE (PerezRiverol et al. 2019) partner repository and can be retrieved with the dataset identifier PXD030401.

\section{MALDI-TOF MS data analysis}

To analyze the subproteome fingerprints of the Tilletia species, two different approaches were conducted. The first one was used to compare the mass spectra to each other by highthroughput multidimensional scaling (HiT-MDS, https:// sourceforge.net/projects/hitmds/) (Strickert et al. 2005) implemented in the GNU Octave (3.8.1) software package, together with hierarchical cluster analysis (HCA). The second approach was performed by discriminant analysis of principal components (DAPC) using the adegenet package (2.0.1) for the RStudio software (1.1.463) (Jombart and Collins 2015). Both procedures were first conducted using a reference set of 52 Tilletia specimens that had been determined to species level without any conflicts by experts. They were then repeated using these and the additional 15 specimens that had been proven to be problematic to determine to species level based on morphological characters (see Table 2).

HiT-MDS was used to detect similarities and calculate the distances between the acquired mass spectra of the Tilletia specimens and to visualize this in a dendrogram. To decrease the complexity of the diagram, consensus spectra were used, where the nine single spectra of each sample were summarized to one mean spectrum. Using an in-house software based on MASCAP, cluster analysis of the condensed mass spectra was performed considering the weighted pair group method with averaging (WPGMA) (Sneath and Sokal 1973) and the normalized dot product to find similarities by comparing the spectra to each other, as described by Frank et al. (2008). The separation of the groups in the resulting dendrogram can be indicated by the reconstruction quality ranging from 0 to 1 , where a good separation is represented by 1 and no separation by 0 .

The second approach, DAPC, was used to detect and visualize the differences of the mass spectra between groups, instead of the similarities, minimizing the variance within the clusters, which is the main difference to the more commonly used principal components analysis (PCA) method (Jombart and Collins 2015). For best results considering the variability of the mass spectra, all individual single spectra of the specimens were applied. Using the adegenet package (2.0.1) for the RStudio software (1.1.463) (Jombart and Collins 2015), the raw data were first transformed using PCA, followed by applying a $\mathrm{k}$-means algorithm with increasing values of $\mathrm{k}$ to identify the optimal number of clusters. Bayesian information criterion (BIC) was used to compare the different clustering solutions where the best one corresponds to the lowest BIC. In this study, the first conspicuous bend in the curve was considered optimal BIC. After choosing the number, DAPC was performed resulting in a bar plot of eigenvalues, a scatterplot which visualizes the individual samples as dots and groups as inertia ellipses, and a table listing 
Table 2 Morphological discrimination and germination behavior of 67 specimens of T. caries, T. laevis, and T. controversa

\begin{tabular}{|c|c|c|c|c|c|c|c|}
\hline $\begin{array}{l}\text { Sample number / } \\
\text { collection } \\
\text { number }\end{array}$ & \multicolumn{3}{|c|}{ Morphology } & \multicolumn{2}{|c|}{ Germination } & \multicolumn{2}{|c|}{$\begin{array}{l}\text { Species identification } \\
\text { (reference set) / test } \\
\text { specimen category }\end{array}$} \\
\hline AA7 & +++ & - & - & $x$ & $\mathrm{x}$ & & \\
\hline AA 8 & +++ & - & - & $x$ & $\mathrm{x}$ & & \\
\hline AA9 & +++ & - & - & $\mathrm{x}$ & $\mathrm{x}$ & & \\
\hline AA10 & +++ & - & - & $x$ & $\mathrm{x}$ & & \\
\hline AA11 & +++ & - & - & $x$ & $\mathrm{x}$ & & \\
\hline AA12 & +++ & - & - & $x$ & $\mathrm{x}$ & & \\
\hline $\mathrm{AC}$ & +++ & - & - & $x$ & $\mathrm{x}$ & & \\
\hline $\mathrm{AD}$ & +++ & - & - & $x$ & $\mathrm{x}$ & & \\
\hline AER & +++ & - & - & $x$ & $\mathrm{x}$ & & \\
\hline AES & +++ & - & - & $x$ & $\mathrm{x}$ & & \\
\hline AEZO & +++ & - & - & $x$ & $\mathrm{x}$ & & \\
\hline AGW & +++ & - & - & $x$ & $\mathrm{x}$ & & \\
\hline AHW & +++ & - & - & $x$ & $\mathrm{x}$ & T. caries & \\
\hline AKW & +++ & - & - & $x$ & $\mathrm{x}$ & & \\
\hline $\mathrm{AL}$ & +++ & - & - & $x$ & $\mathrm{x}$ & & \\
\hline AL15 & +++ & - & - & $x$ & $\mathrm{x}$ & & \\
\hline AN & +++ & - & - & $\mathrm{x}$ & $\mathrm{x}$ & & \\
\hline AN15 & +++ & - & - & $x$ & $\mathrm{x}$ & & \\
\hline $\mathrm{AO}$ & +++ & - & - & $x$ & $\mathrm{x}$ & & \\
\hline AS14 & +++ & - & - & $x$ & $\mathrm{x}$ & & \\
\hline AW & +++ & - & - & $x$ & $\mathrm{x}$ & & \\
\hline $\mathrm{T}-2$ & +++ & - & - & $x$ & $\mathrm{x}$ & & \\
\hline $\mathrm{T}-15$ & +++ & - & - & $x$ & $\mathrm{x}$ & & \\
\hline $\mathrm{T}-19$ & +++ & - & - & $\mathrm{x}$ & $\mathrm{x}$ & & \\
\hline $\mathrm{T}-33$ & +++ & - & - & $\mathrm{x}$ & $\mathrm{x}$ & & $\grave{0}$ \\
\hline L-10 & - & +++ & - & $\mathrm{x}$ & $\mathrm{x}$ & T. laevis & $\begin{array}{l}n \\
8\end{array}$ \\
\hline L-16 & - & +++ & - & $x$ & $\mathrm{x}$ & & - \\
\hline L-18 & - & +++ & - & $x$ & $\mathrm{x}$ & & $\stackrel{\overline{0}}{\ddot{\theta}}$ \\
\hline L-19 & - & +++ & - & $x$ & $\mathrm{x}$ & & \\
\hline L-20 & - & +++ & - & $x$ & $\mathrm{x}$ & & \\
\hline L-21 & - & +++ & - & $x$ & $\mathrm{x}$ & & \\
\hline D-3 & - & - & +++ & - & $\mathrm{x}$ & & \\
\hline D-4 & - & - & +++ & - & $\mathrm{x}$ & & \\
\hline D-12 & - & - & +++ & - & $\mathrm{x}$ & & \\
\hline D-13 & - & - & +++ & - & $\mathrm{x}$ & & \\
\hline D-17 & - & - & +++ & - & $\mathrm{x}$ & & \\
\hline D-18 & - & - & +++ & - & $\mathrm{x}$ & & \\
\hline OA1 & - & - & +++ & - & $\mathrm{x}$ & & \\
\hline $\mathrm{OA} 2$ & - & - & +++ & - & $\mathrm{x}$ & T. controversa & \\
\hline OA3 & - & - & +++ & - & $\mathrm{x}$ & & \\
\hline OA5 & - & - & +++ & - & $\mathrm{x}$ & & \\
\hline OA6 & - & - & +++ & - & $\mathrm{x}$ & & \\
\hline $\mathrm{OC} 1$ & - & - & +++ & - & $\mathrm{x}$ & & \\
\hline $\mathrm{OC} 2$ & - & - & +++ & - & $\mathrm{x}$ & & \\
\hline $\mathrm{OL}$ & - & - & +++ & - & $\mathrm{x}$ & & \\
\hline OL14 & - & - & +++ & - & $\mathrm{x}$ & & \\
\hline
\end{tabular}


Table 2 (continued)

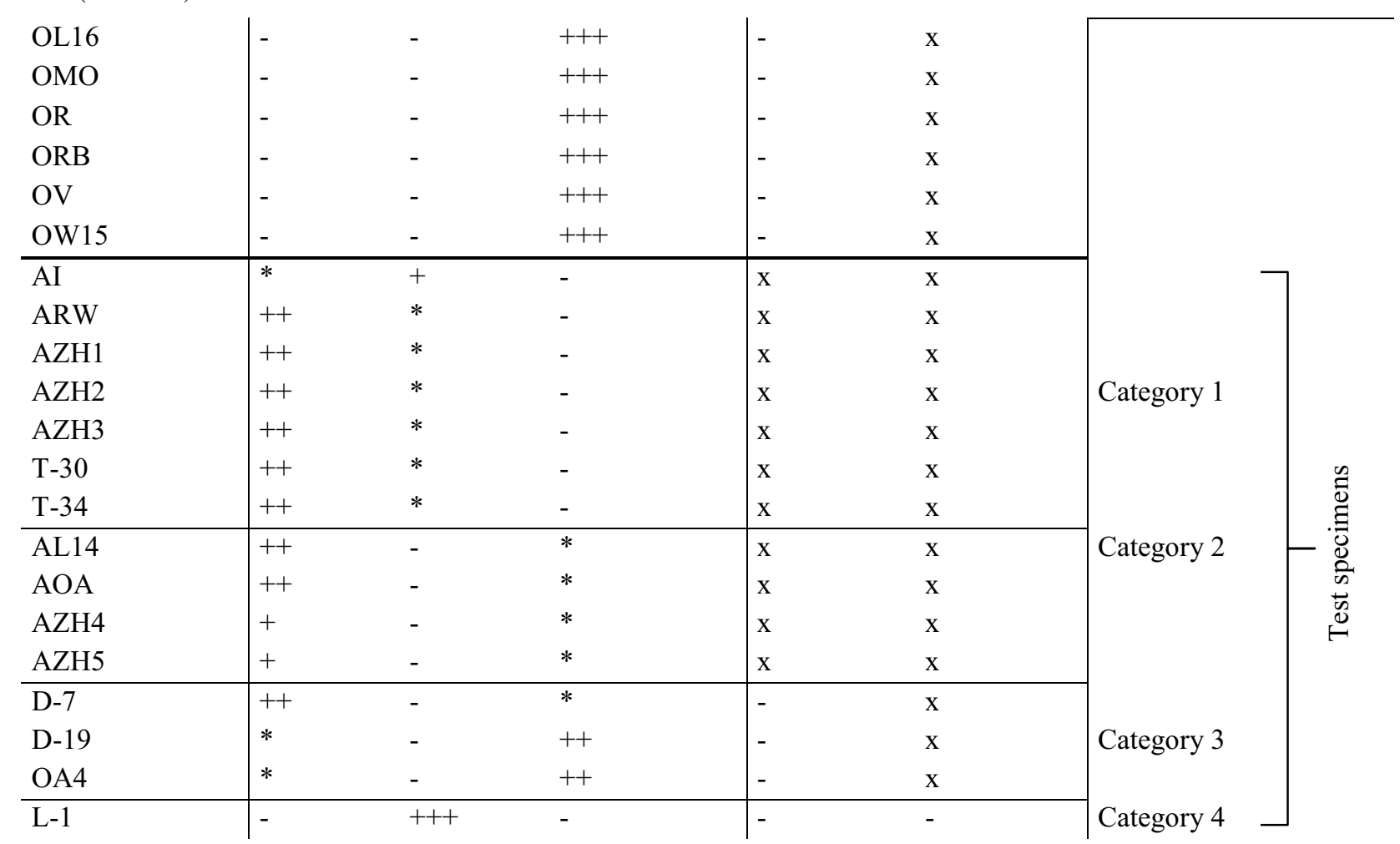

+++ , identically identified by seven experts; ++ , predominantly identified by 5 or 6 experts; + , predominantly identified by 4 experts; $*$, alternative species identification by minority group; $x$, triplicates germinated at corresponding temperature; - , negative

the single spectra of each specimen per group. Grouping rules of DAPC demand that a minimum of six out of nine single spectra $(66.67 \%)$ must cluster together in the same group to reliably assign a specimen to a group. In this study, also specimens only clustering the majority of the nine single spectra to one single group were considered accordingly and marked in Table 3 . The main peaks responsible for the separation (of the specimens) were illustrated in a loading plot. To discover the main differences between the two groups in more detail, the DAPC was also performed pairwise based on the grouping by the main DAPC.

\section{Classification and accuracy of species discrimination by the developed MALDI-TOF MS method}

To determine the final species classification by MALDITOF MS, the results of both HCA and DAPC approaches were combined. These composite classification results were compared to the species determination results obtained by morphology and germination behavior. The accuracy of the MALDI-TOF MS method was then calculated as follows:

\section{Results}

\section{Defining reference material and test specimens by morphology and germination behavior}

From the 67 specimens of T. caries, T. laevis, and T. controversa studied, 25 were unambiguously determined based on their morphological characteristics as T. caries, 7 as $T$. laevis, and 21 as $T$. controversa (see Table 2). Germination behavior was used as a second character for the identification of specimens. Teliospores of 43 specimens germinated at $5{ }^{\circ} \mathrm{C}$ as well as at $15{ }^{\circ} \mathrm{C}$ and were, based on this criterion, defined as one of the two causal agents of common bunt, T. caries or T. laevis. The remaining 24 specimens germinated exclusively at $5{ }^{\circ} \mathrm{C}$ and were thus defined as T. controversa. Combining the results, we defined a reference set of 52 specimens which could clearly be attributed to one of the three Tilletia species and this collection was subsequently used to optimize the MALDI-TOF MS. Each of these specimens showed both the species-specific germination behavior as well as the typical morphological characteristics. Within the common bunt species, T. caries and $T$.

Accuracy $[\%]=($ correct species classification/total tested specimens $) \times 100$ 
Table 3 List of DAPC-based grouping of 52 Tilletia reference specimens and all 67 Tilletia specimens including 15 test specimens regarding the scatterplots in Fig. 5a and b

\begin{tabular}{|c|c|c|c|c|c|c|c|}
\hline \multicolumn{2}{|l|}{ Group 1} & \multicolumn{2}{|l|}{ Group 2} & \multicolumn{2}{|l|}{ Group 3} & \multicolumn{2}{|l|}{ Group 4} \\
\hline $\begin{array}{l}\text { Reference speci- } \\
\text { mens }\end{array}$ & $\begin{array}{l}\text { + Test speci- } \\
\text { mens }\end{array}$ & $\begin{array}{l}\text { Reference speci- } \\
\text { mens }\end{array}$ & $\begin{array}{l}+ \text { Test speci- } \\
\text { mens }\end{array}$ & $\begin{array}{l}\text { Reference speci- } \\
\text { mens }\end{array}$ & $\begin{array}{l}\text { + Test speci- } \\
\text { mens }\end{array}$ & $\begin{array}{l}\text { Reference } \\
\text { specimens }\end{array}$ & + Test specimens \\
\hline $\mathrm{D}-12^{\mathrm{a}}$ & D-12 & L-10 & L-10 & AA7 & AA7 & $\mathrm{AL}$ & $\mathrm{AL}$ \\
\hline D-13 & D-13 & $L-16(4,3)^{\mathrm{d}}$ & L-16 & AA8 & AA8 & AL15 & AL15 \\
\hline D-17 & D-17 & L-18 & L-18 (4) & AA9 & AA9 & $\mathrm{AN}$ & $\mathrm{AN}$ \\
\hline D-18 & D-18 & L-19 & L-19 & AA10 & AA10 & AN15 & AN15 \\
\hline OA1 & OA1 (4) & L-20 & L-20 & AA11 & AA11 & $\mathrm{AO}(3)$ & $A O(2,3)$ \\
\hline OA2 & $\mathrm{OA} 2(4,2)$ & L-21 & L-21 & AA12 & AA12 & D-3 & D-3 \\
\hline OA3 & OA3 & $\mathrm{T}-2$ & $\mathrm{~T}-2$ & $\mathrm{AC}$ & $\mathrm{AC}$ & D-4 & D-4 \\
\hline OA5 & OA5 & $\mathrm{T}-19(4,3)$ & T-19 $(3,4)$ & $\mathrm{AD}$ & $\mathrm{AD}$ & $\mathrm{T}-15$ & $\mathrm{~T}-15(2)$ \\
\hline OA6 $(4)^{\mathrm{b}}$ & - & $\mathrm{T}-33$ (4) & $\mathrm{T}-33$ & AER & AER & & OA6 $(1,2)$ \\
\hline $\mathrm{OC} 1$ & $\mathrm{OC} 1$ & & AZH2 & AES & AES & & AL14 \\
\hline $\mathrm{OC} 2$ & $\mathrm{OC} 2$ & & L-1 & AEZO & AEZO & & \\
\hline $\mathrm{OL}$ & OL & & $\mathbf{T}-30$ & $\mathrm{AGW}(4)$ & AGW & & \\
\hline OL14 & OL14 & & T-34 & AHW & AHW & & \\
\hline OL16 & OL16 & & & AKW & AKW & & \\
\hline OMO & OMO & & & AS14 (4) & AS14 & & \\
\hline OR & OR & & & AW & AW & & \\
\hline ORB & ORB & & & & AI (4) & & \\
\hline OV & OV & & & & AOA & & \\
\hline OW15 & OW15 & & & & ARW & & \\
\hline & $\operatorname{AZH3}(3)^{c}$ & & & & AZH1 $(\mathbf{1 , 4 )}$ & & \\
\hline & D-7 & & & & AZH4 & & \\
\hline & D-19 & & & & AZH5 $(4,2)$ & & \\
\hline & OA4 & & & & & & \\
\hline
\end{tabular}

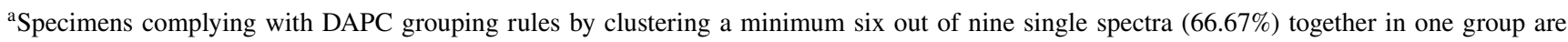
unmarked

${ }^{\mathrm{b}}$ Specimens clustering five single spectra (55.55\%) to one group (majority group). Allocation of up to four single spectra to other groups (minority group) are given in brackets by decreasing order

${ }^{\mathrm{c}} 15$ test specimens are bold

${ }^{\mathrm{d}}$ Two specimens presented in italics had only four spectra in the majority group and five spectra in two other groups

laevis were indistinguishable in their germination behavior but had a distinct morphology. Fourteen further specimens could not be determined unequivocally by their morphological characteristics and one did not germinate. These inconsistently determined specimens $(n=15)$ were defined as the set of test specimens to be identified during the current study and categorized in four different groups as follows (see Table 2): seven specimens were grouped in category 1 , which contains six specimens that morphologically were predominantly identified as $T$. caries by five to six experts with a low identification score for T. laevis, while one specimen was identified as $T$. laevis by four and as T. caries by three experts. The germination behavior supported that the specimens belonged to one of the two causal agents of common bunt $-T$. caries or T. laevis. Category 2 contained four specimens that were morphologically identified as $T$. caries by the majority of the experts but had also a low identification score for $T$. controversa, albeit germination tests identified them as one of the common bunt species T. caries or T. laevis. Category 3 contained three specimens with low identification scores both in $T$. caries and $T$. controversa with germination results that clearly identified them as $T$. controversa. One specimen that was clearly identified morphologically as $T$. laevis, but did not germinate at any temperature regime, was assigned to category 4.

\section{Differentiation of $T$. caries and $T$. controversa by mass spectra comparison}

Figure 1a shows a stack of nine single spectra obtained from teliospores of both strains, whereas Fig. 1b shows a stack of nine single spectra obtained from mycelia of both 


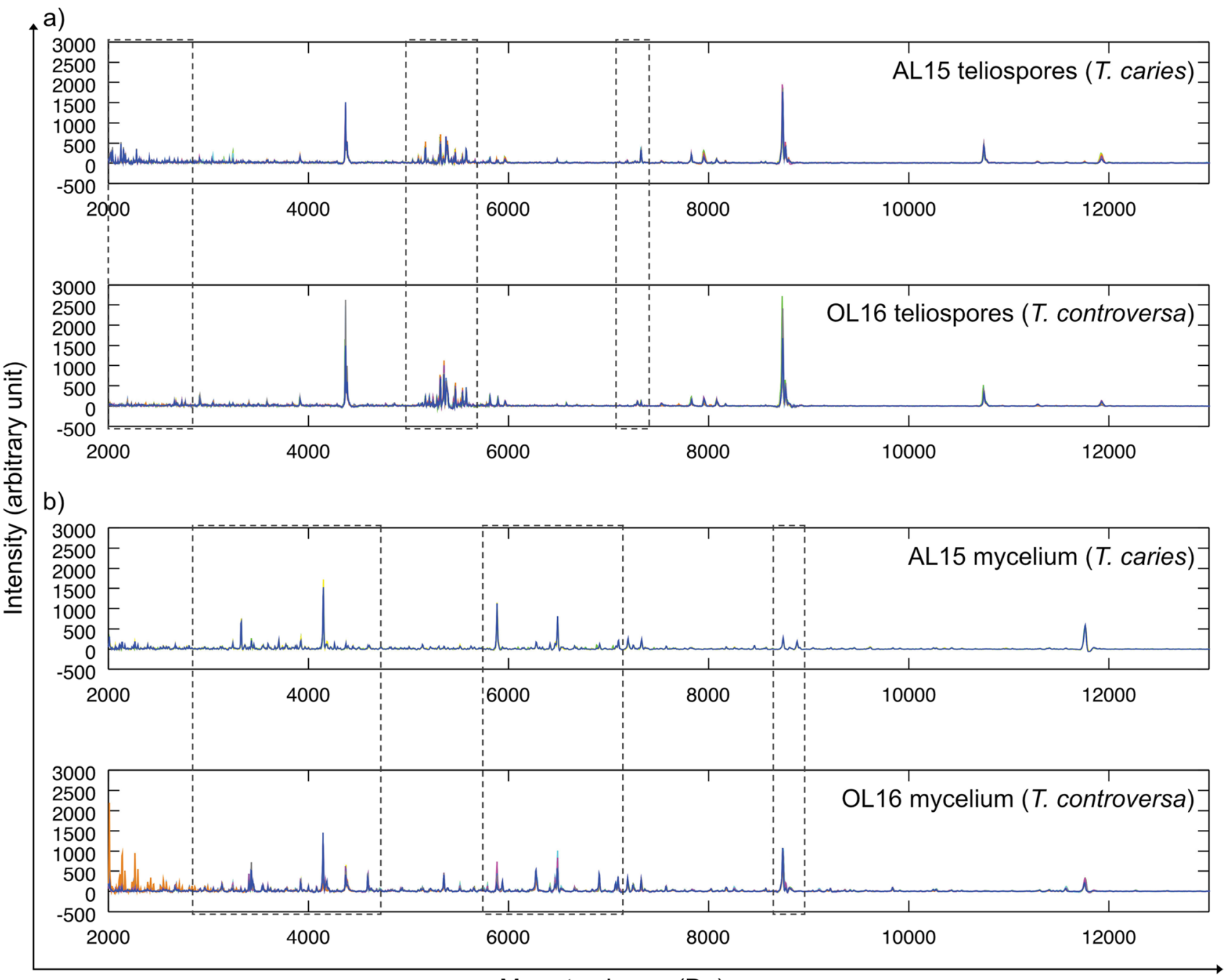

Mass to charge $(\mathrm{Da})$

Fig. 1 Stacked view of MALDI-TOF MS spectra visualizing the comparison of profiles of $T$. caries specimen AL15 and T. controversa specimen OL16 obtained by MALDI-TOF mass spectrometry using a teliospores as the starting material, $\mathbf{b}$ mycelium as the starting material. Overlapping peaks that were identical in location and intensity

specimens using a similar preparation method. Comparing the teliospore-based spectra of both specimens showed major differences between individual spectra within three $\mathrm{m} / \mathrm{z}$ ranges, i.e., in the $\mathrm{m} / \mathrm{z}$ range of 2000 to 2700,5000 to 5500 , and around 7300 . The major peak differences between single spectra of mycelial preparations of specimens AL15 and OL16 were located in three $\mathrm{m} / \mathrm{z}$ ranges between 3000 and 4500 as well as 5900 and 7100 and around 8900 .

The individual density plots shown in Fig. 2a resulted from the DAPC analysis of all the single mass spectra $(n=9)$ obtained for each specimen. It showed a clear in all nine single spectra of a stack are shown in blue color, whereas peaks that occurred only in individual spectra or had divergent intensities are visualized in other colors. The parts of the mass spectra that were different between the two specimens are highlighted with boxes

separation between $T$. controversa (blue, left side) and T. caries (red, right side). This difference occurred both in teliospore-based spectra and in mycelium-based spectra. Additionally, the narrowness of the density plot per specimen indicated a high degree of similarity of the nine single spectra within each specimen, both with teliospores and mycelia. All differentiation peaks between $T$. caries and $T$. controversa obtained by DAPC exceeding the threshold of 0.02 were visualized by loading plots and labeled with their $\mathrm{m} / \mathrm{z}$ value (see Fig. 2b). Data corresponded well with the $\mathrm{m} / \mathrm{z}$ areas that were highlighted in Fig. 1. 
a)

Individual density plot

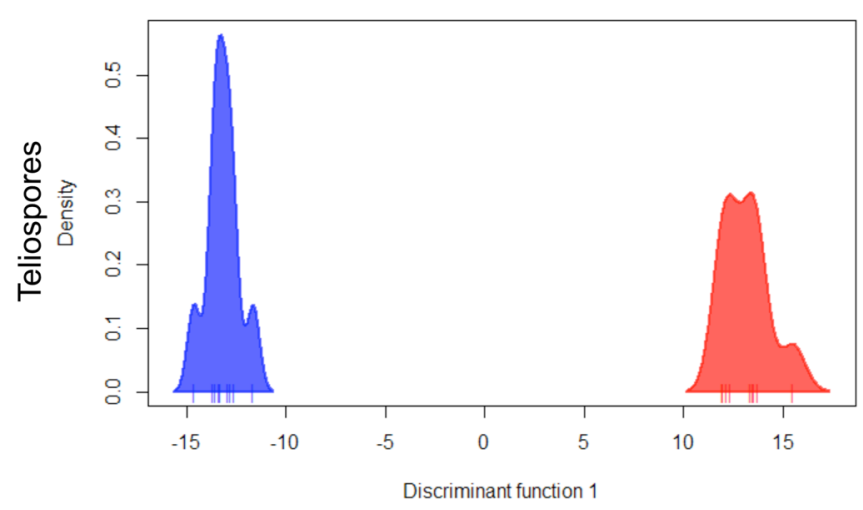

Individual density plot

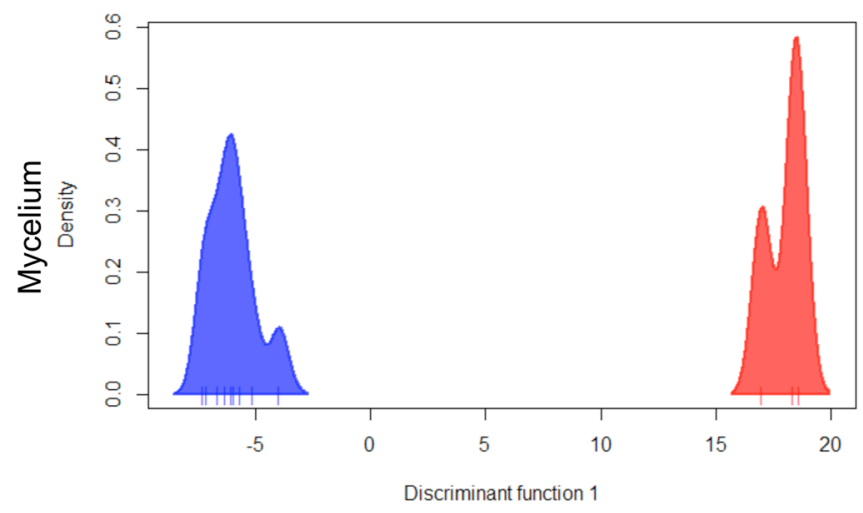

Fig. 2 Illustration of discriminant analysis of principal components (DAPC) performed with each nine single MALDI-TOF mass spectra. a Individual density plot of teliospores (top) and mycelium (bottom) of the two specimens AL15 (red, right) and OL16 (blue, left); b load-

\section{Clustering of reference material and test specimens using hierarchical cluster analysis of MALDI-TOF MS data}

In total, teliospores of 69 Tilletia specimens (52 reference specimens, 15 test specimens, and $2 T$. indica specimens as outgroup) were analyzed by MALDI-TOF MS using our optimized protocol. The hierarchical cluster analysis (HCA) dendrogram shown in Fig. 3 visualizes the clustering of the 52 reference samples. The two karnal bunt specimens (T. indica IM5 and II7) serving as outgroup in the HCA were clearly separated from all common and dwarf bunt reference samples. The reference samples formed two major clusters. Cluster 1 included all specimens identified as $T$. controversa. Cluster 2 included all T. caries and T. laevis specimens. Adding the 15 test specimens (bold type) to the HCA resulted in the dendrogram depicted in Fig. 4. The three specimens belonging to the test specimen category 3 and another three belonging to category 1 clustered together with T. controversa specimens in cluster 1 . The four remaining b)

Loading plot
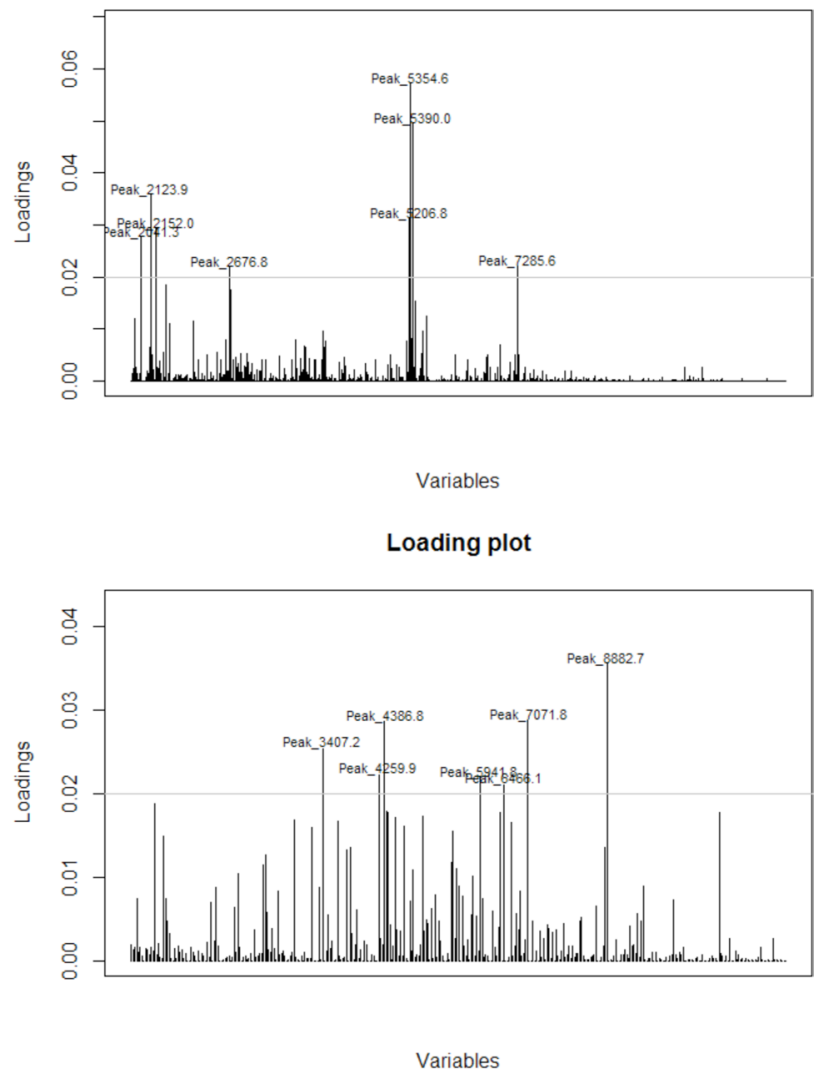

ing plot of single spectra comparison showing peaks used for differentiation between AL15 and OL16 (top teliospores, bottom mycelium)

specimens out of category 1 plus the four belonging to category 2 grouped together with reference samples of $T$. caries and $T$. laevis in cluster 2 . The one test sample L- 1 out of category 4 formed a clearly separated branch of its own that was basal to cluster 1 and 2 and was assigned as cluster 0 in Fig. 4 .

\section{Discriminant analysis of principal components used as an alternative clustering method}

Separation of the Tilletia specimens by DAPC was chosen as an alternative approach. Grouping was based on nine single mass spectra from each specimen. Grouping of all 69 specimens from the current study resulted in a scatter plot that clearly separated the two $T$. indica specimens from the other bunt species but lacked resolution in all other specimens (see Online Resource Fig. S1). To increase the resolution, the outgroup was excluded to perform further DAPC analyses with three discriminant components. Under this condition, DAPC allocated the 52 reference specimens to four distinct groups as demonstrated in the scatter plot shown in Fig. 5a. Based on 
Fig. 3 Hierarchical cluster analysis of 54 Tilletia specimens (reference set) displayed in a dendrogram based on the consensus spectra of nine single spectra per specimen. Two karnal bunt specimens ( $T$. indica) served as outgroup. Cluster 1 included dwarf bunt specimens (T. controversa, marked in blue, top), cluster 2 included common bunt specimens (T. caries and T. laevis, marked in orange, bottom)

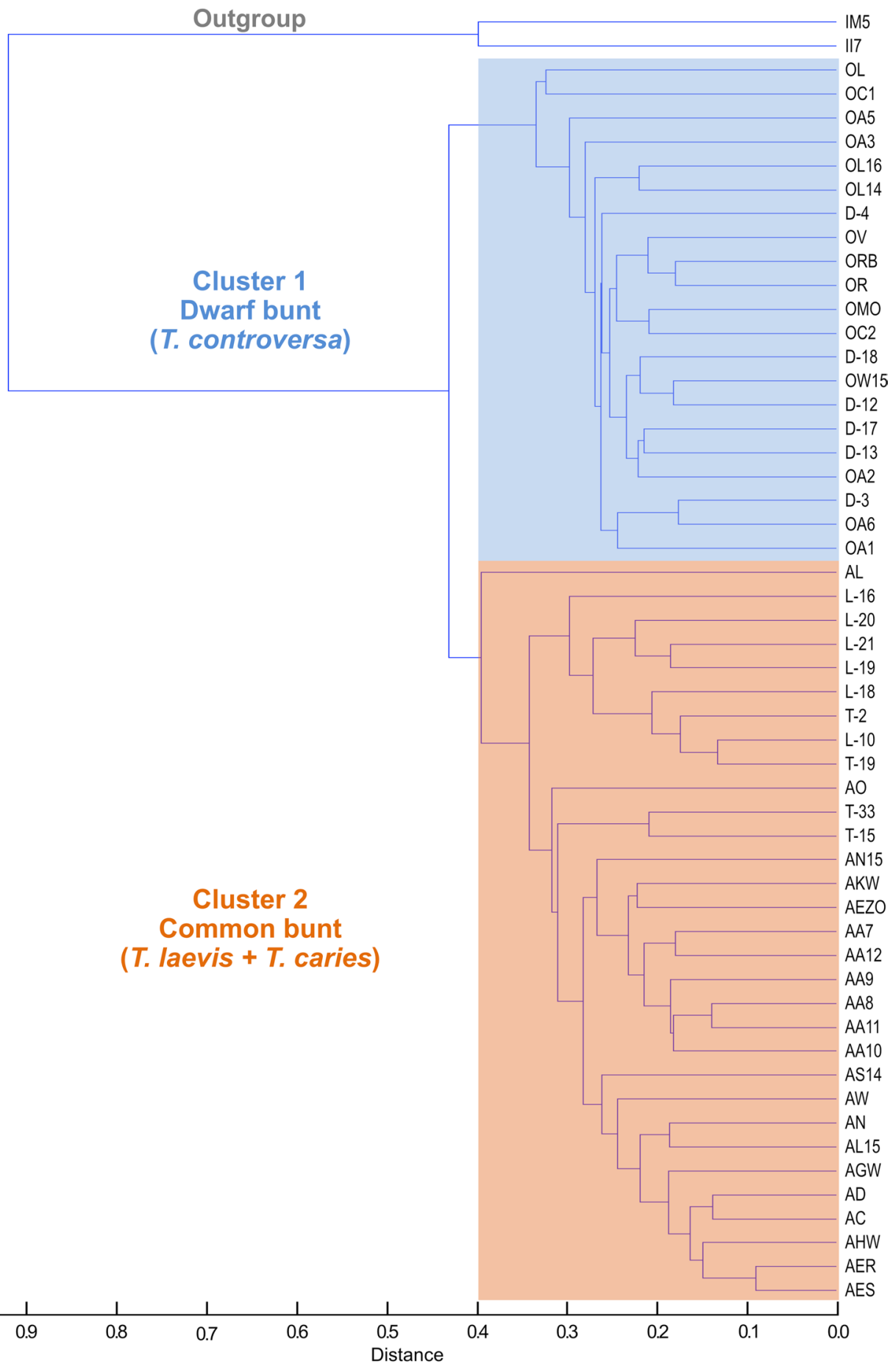

Density plots of individually performed pairwise DAPCs visualize the clear separation of the pairings of groups 1 and 2, 1 and 3 as well as 2 and 3, in contrast to all pairings including group 4 showing reduced distances of the plots (see Online Resource Fig. S2). Each pair showed a specific major peak profile (Loading plots) that was crucial for the separation of DAPC groups. The loading plot produced from the data of 52 reference specimens showed that the major peaks at $\mathrm{m} / \mathrm{z} 2023.1,2455.4$, and 3289.9 were the decision caries and T. laevis specimens clustered (see also Table 3 ). 
Fig. 4 Hierarchical cluster analysis of 69 Tilletia specimens (including 15 test specimens) displayed in a dendrogram based on the consensus spectra of nine single spectra per specimen. Two karnal bunt specimens (T. indica) served as outgroup. Cluster 1 mainly included dwarf bunt specimens (T. controversa, marked in blue, middle), cluster 2 included common bunt specimens ( $T$. caries and T. laevis, marked in orange, bottom). Cluster 0 included one T. laevis specimen (marked in green, top). The 15 test specimens are highlighted in bold type

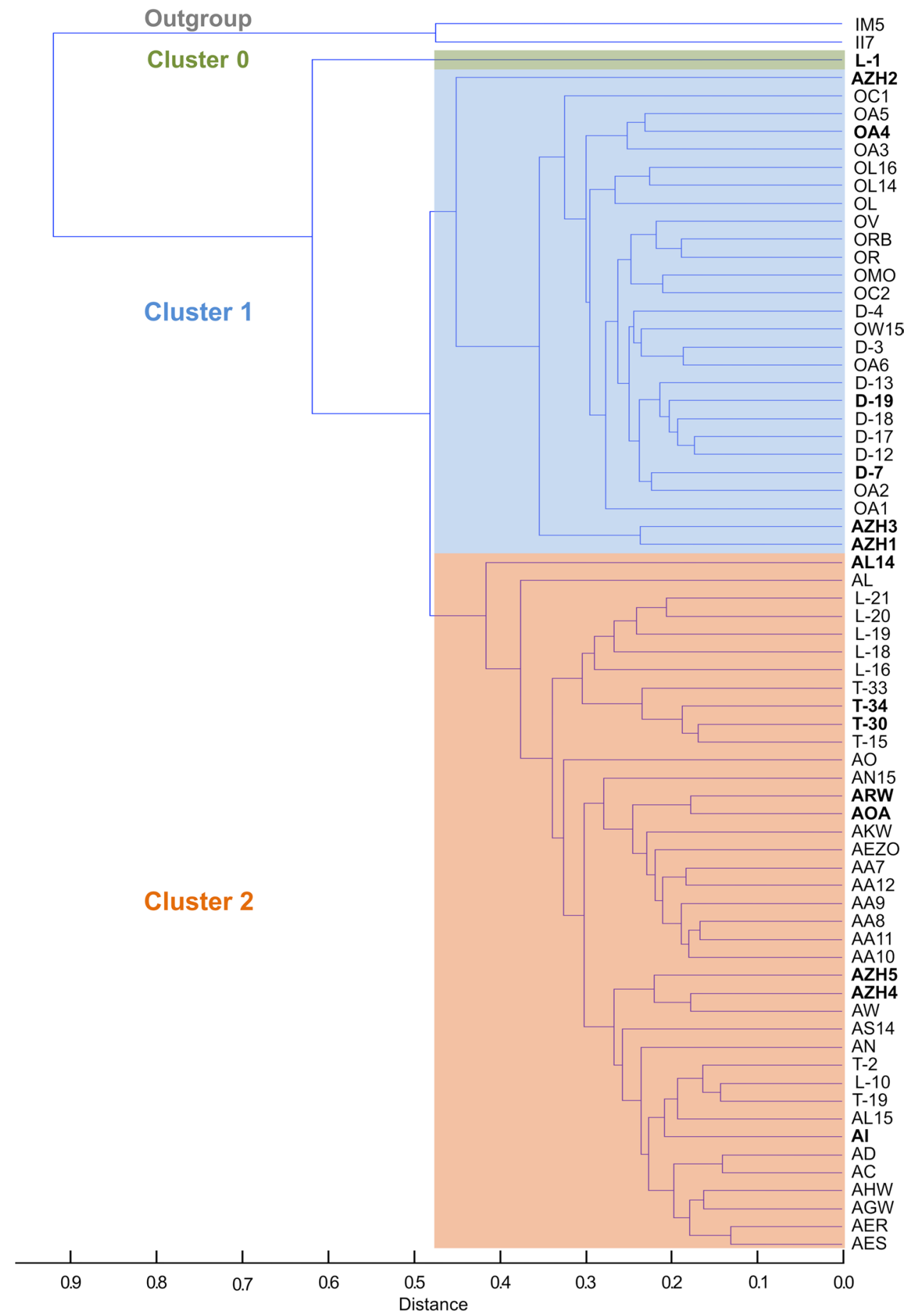

criteria for the discrimination of $T$. controversa (group 1) and T. caries/T. laevis (groups 2-4, see Fig. 5c).

When spectra of the 15 test specimens were added to the analysis, the scatter plot of the DAPC looked similar to the previous analysis of reference specimens (compare Fig. 5a with Fig. 5b). Beside the allocation of the additional samples to the four groups (test specimens highlighted in bold type, see Table 3), few changes regarding the reference set specimens became obvious. One T. laevis
(L-16) and one $T$. caries (T-33) specimen (group 2) as well as T. caries specimens AGW and AS14 (group 3) increased the number of single spectra in the respective groups now comprising more than $66 \%$. In contrast, one or two single spectra of specimens OA1, OA2 (both group 1), L-18 (group 2), AO, and T-15 (both group 4) were transferred to other groups when test specimens were integrated with the analysis. The greatest shift was observed for specimen OA6. The nine single spectra were split between the 
a)

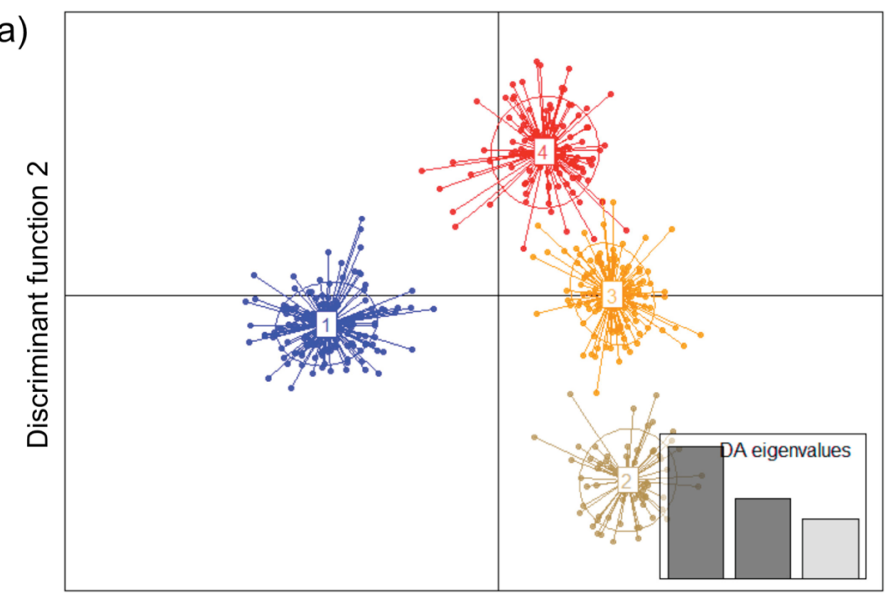

Discriminant function 1

b)

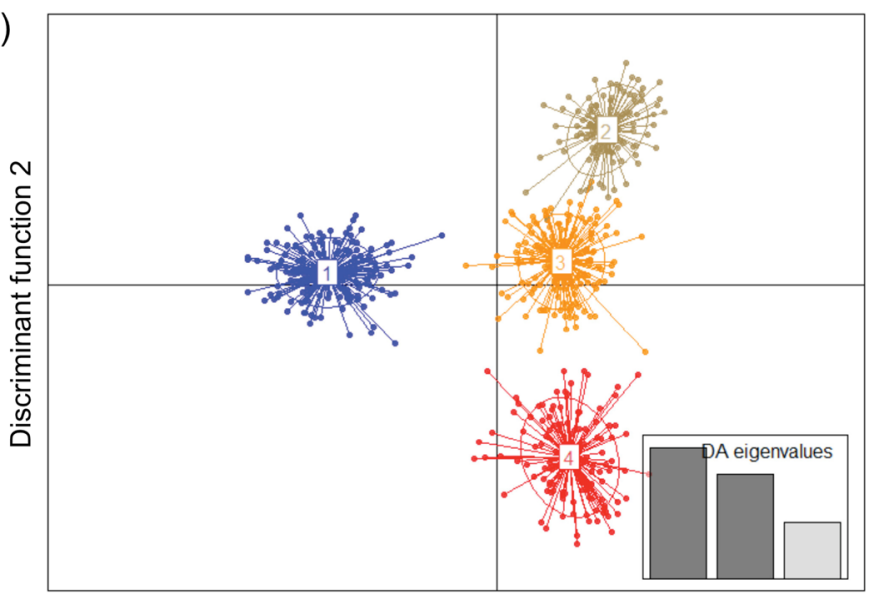

Discriminant function 1

Fig. 5 Scatterplot of a discriminant analysis of principal components (DAPC) performed with each of nine single MALDI-TOF mass spectra per specimen using teliospores from a 52 Tilletia specimens (ref-

same two groups (1 and 4) in both analyses. However, the change of allocation of two single spectra from group 1 to group 4 and 2 resulted in a new assignment of reference specimen OA6 to group 4 (see Table 3).

\section{Classification of the 15 test specimens and evaluation of the MALDI-TOF MS method}

Finally, the 15 test specimens were classified as $12 \mathrm{com}-$ mon bunt species (T. caries/T. laevis) and 3 dwarf bunt species ( $T$. controversa), combining the three identification criteria, morphology, germination behavior, and MALDITOF MS (Table 4). HCA clustering and DAPC grouping were summarized in the MALDI-TOF MS classification as dwarf bunt or common bunt because no unambiguous species allocation was possible on the basis of the mass spectrometry data equivalent to germination behavior. Comparing the final species classification with the individual c)

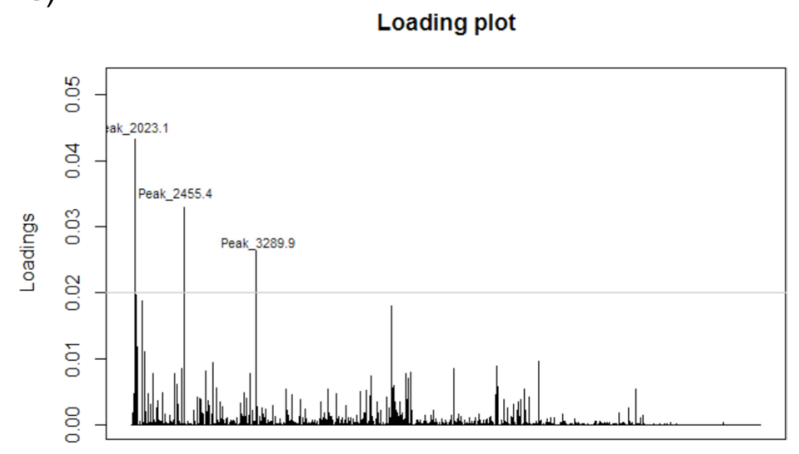

Variables erence set) and b 67 Tilletia specimens (reference set plus test specimens); c loading plot visualizing major peak differences between group 1 and groups $2-4$

results of species determination by MALDI-TOF MS, four test specimens, namely AZH1, AZH2, AZH3, and L-1, were falsely not classified as $T$. caries or $T$. laevis by HCA. On the other hand, by DAPC, only one of the test specimens (AZH3) was falsely classified as $T$. controversa. However, additionally, three $T$. controversa reference specimens, namely D-3, D-4, and OA6, clustered with seven $T$. caries specimens by DAPC, indicating a false classification as T. caries. In Table 5, the number of the false classified specimens by MALDI-TOF MS and the corresponding accuracy in percentage for each analysis method, HCA and DAPC, evaluated individually as well as combined, is shown. The combined final classification comprised the highest accuracy of $100.00 \%$ for the reference set and $98.51 \%$ for all specimens including the test set, respectively, as compared with both single MALDITOF MS data analysis methods. 
Table 4 Classification of the 15 test specimens based on three different criteria

\begin{tabular}{|c|c|c|c|c|c|c|c|}
\hline Test specimen & Sample no & Morphology & Germination $^{\mathrm{b}}$ & HCA cluster $^{c}$ & $\begin{array}{l}\text { DAPC } \\
\text { group }^{\text {d }}\end{array}$ & MALDI-TOF MS & Final classification \\
\hline \multirow[t]{7}{*}{ Category 1} & $\mathrm{AI}$ & T. laevis $>T$. caries & Common bunt & 2 & 3 & Common bunt & Common bunt \\
\hline & ARW & T. caries $>$ T. laevis & Common bunt & 2 & 3 & Common bunt & Common bunt \\
\hline & AZH1 & T. caries $>$ T. laevis & Common bunt & 1 & 3 & Common bunt & Common bunt \\
\hline & $\mathrm{AZH} 2$ & T. caries $>$ T. laevis & Common bunt & 1 & 2 & Common bunt & Common bunt \\
\hline & AZH3 & T. caries $>$ T. laevis & Common bunt & 1 & 1 & Dwarf bunt & Common bunt \\
\hline & $\mathrm{T}-30$ & T. caries $>$ T. laevis & Common bunt & 2 & 2 & Common bunt & Common bunt \\
\hline & $\mathrm{T}-34$ & T. caries $>$ T. laevis & Common bunt & 2 & 2 & Common bunt & Common bunt \\
\hline \multirow[t]{4}{*}{ Category 2} & AL14 & T. caries $>T$. controversa & Common bunt & 2 & 4 & Common bunt & Common bunt \\
\hline & $\mathrm{AOA}$ & T. caries $>T$. controversa & Common bunt & 2 & 3 & Common bunt & Common bunt \\
\hline & AZH4 & T. caries $>T$. controversa & Common bunt & 2 & 3 & Common bunt & Common bunt \\
\hline & AZH5 & T. caries $>T$. controversa & Common bunt & 2 & 3 & Common bunt & Common bunt \\
\hline \multirow[t]{3}{*}{ Category 3} & D-7 & T. caries $>T$. controversa & Dwarf bunt & 1 & 1 & Dwarf bunt & Dwarf bunt \\
\hline & D-19 & T. controvers $a>T$. caries & Dwarf bunt & 1 & 1 & Dwarf bunt & Dwarf bunt \\
\hline & OA4 & T. controvers $a>T$. caries & Dwarf bunt & 1 & 1 & Dwarf bunt & Dwarf bunt \\
\hline Category 4 & L-1 & T. laevis & - & 0 & 2 & Common bunt & Common bunt \\
\hline
\end{tabular}

${ }^{a}$ Morphological discrimination by 7 experts. Majority $>$ minority

${ }^{\mathrm{b}}$ Species specific germination behavior at $5{ }^{\circ} \mathrm{C}$ and $15{ }^{\circ} \mathrm{C}$ (dwarf bunt only $5{ }^{\circ} \mathrm{C}$, common bunt at both temperatures)

${ }^{\mathrm{c}}$ Clustering based on MALDI-TOF MS data analysis by hierarchical cluster analysis (HCA); 1 T. controversa, 2 T. caries/T. laevis, 0 outgroup

${ }^{\mathrm{d}}$ Clustering based on MALDI-TOF MS data analysis by discriminant analysis of principal components (DAPC); 1 T. controversa, 2 T. caries/T. laevis, 3 T. caries, 4 T. caries/T. controversa

${ }^{\mathrm{e}}$ Classification by MALDI-TOF MS (DAPC $>$ HCA)

Table 5 Accuracy of the new developed MALDI-TOF MS method to classify Tilletia species to common and dwarf bunt using teliospores

\begin{tabular}{lllll}
\hline & & \multicolumn{3}{l}{ MALDI-TOF MS } \\
\cline { 3 - 5 } & & HCA & DAPC & Final classification \\
\hline Reference set $(N=52)$ & False classification (quantity) & 0 & 2 & 0 \\
& Accuracy $(\%)$ & 100.00 & 96.15 & 100.00 \\
All specimens incl. test & False classification (quantity) & 4 & 4 & 1 \\
set $(N=67)$ & Accuracy $(\%)$ & 94.03 & 94.03 & 98.51 \\
\hline
\end{tabular}

${ }^{a}$ Classification results were referred to the germination test, except L-1 which was referred to as the unequivocal morphological identification

\section{Discussion}

\section{Reference material and test specimens}

In seed testing, the causal agents of common bunt and dwarf bunt of wheat are identified based on the morphological characteristics of their teliospores such as reticulation of the spore surface, diameter and height of the muri, and presence or absence of hyaline, gelatinous sheaths (ISTA 1984; Vánky 2012). In the present study, it was attempted to identify 67 Tilletia specimens combining morphological characters with germination behavior of teliospores (Meiners and Waldher 1959) as a baseline for testing and establishing MALDI-TOF MS as an alternative identification method. Doing this, 52 specimens could be unequivocally determined to species level as $T$. caries, T. laevis, or T. controversa, respectively. Some conflicts remained in morphological identification of 15 species, which constituted a set of interesting test samples to examine the suitability of the developed MALDI-TOF MS method. Fourteen of them were inconsistently determined as T. caries, T. laevis, and T. controversa based on the morphological characteristics. Due to a broad range of variability in distinguishing characteristics, especially in spore wall markings and natural hybridization, differentiation of closely related T. caries, T. laevis, and T. controversa is not always that clear (Holton and Kendrick 1956; 
Silbernagel 1964; Hess and Trione 1986). But all these 14 specimens could be reliably classified as one of the common bunt species, T. caries and T. laevis or the dwarf bunt species $T$. controversa according to their germination behavior. The remaining test specimen, L-1, morphologically uniquely defined as $T$. laevis, did not germinate and could therefore not be assigned to the reference set (see Table 2).

\section{Method development}

Originally, MALDI-TOF MS was developed to identify bacteria, followed by application to clinically relevant filamentous fungi (Wieser et al. 2012). The first analyzed fungal spores belonged to Ascomycota and Oomycota, where no pretreatment was necessary to extract proteins and peptides in relevant amounts and quality (Chen and Chen 2005; Chalupová et al. 2012). Teliospore cell walls of several Basidiomycota, in particular smut fungi, are thick-walled consisting of several spore wall layers. Therefore, a pretreatment is often necessary in order to liberate proteins and peptides for subsequent MALDI-TOF MS analyses (Taskova et al. 2006; Piepenbring 2009). In the current study, subproteomic mass spectra of $T$. caries and $T$. controversa mycelia were successfully generated using the sample preparation protocol of Cassagne et al. (2011), which has frequently been used for MS profiling of filamentous fungi and yeasts (Lau et al. 2013; Usbeck et al. 2013; Lauterbach et al. 2017; Wigmann et al. 2019). However, these protocols did not deliver high-quality mass spectra when using teliospores of Tilletia species without any pretreatment. Previous studies demonstrated that mechanical disruption of fungal spores resulted in higher quantities of proteins as compared to the concentrations obtained by spontaneous protein leakage (Banowetz and Doss 1994). In the meantime, several studies optimized the procedure using bead-beating homogenizers, e.g., for conidia of Aspergillus and Penicillium (Hettick et al. 2008a, b) and for clinical mold isolates including different basidiomycetes (Luethy and Zelazny 2018). Sulc et al. (2009) and Beinhauer et al. (2016) demonstrated that in addition to the quality of the mechanical disruption of spores, also the number of fungal spores per treatment must be at an optimum to yield good mass spectrometry results. In the current study, concentrations between 1 and $5 \mathrm{mg}$ of teliospores were tested, resulting in an optimal signal-to-noise ratio at $3 \mathrm{mg}$, which is equivalent to ca. $10^{6}$ teliospores of Tilletia spp. (data not shown). Beside the concentrations of proteins and byproducts, also the way in which samples are applied to the MALDI-TOF MS target plate has a considerable influence on the quality of spectra. Comparing different preparation techniques, the sandwich method, applying matrix-aliquot-matrix, yielded the most satisfactory mass spectra in combination with $\alpha$-CHCA matrix, which is tolerant towards volatile contaminants (Kussmann et al. 1997), which are supposed to exist in Tilletia teliospores (Holton et al. 1968). Using the developed method for MALDI-TOF MS-based teliospore analysis, we were able to create reproducible mass spectra of one specimen each of T. caries and T. controversa which could clearly separate both species. Comparison of spectra produced from their mycelia showed that the teliospore-based spectra produced similar numbers of peaks, albeit with lower intensities, but still strong enough to be clearly resolved by the MASCAP algorithm (Mantini et al. 2010). Also, the results of DAPC showed a clear separation of the two species along with a discriminant function (Fig. 2a) based on the major peak differences visualized in the loading plots (Fig. 2b). This means that teliospore-based analysis equals its mycelium-based equivalent in quality with the advantage of skipping the timeconsuming germination and cultivation step.

\section{Classification of reference specimens using HCA and DAPC}

Analysis of the 52 Tilletia reference specimens alone aimed at obtaining a general grouping that allowed the distinction of the three species. The results presented here clearly demonstrate that the interpretation of mass spectra and the resulting species identification strongly depends on the method used for data clustering. HCA and DAPC were used for the clustering of spectra in the current study. Several previous studies have used either one or both analysis methods to differentiate closely related taxa of bacteria, fungi, or yeasts (Hettick et al. 2008a, b; Usbeck et al. 2013; Kehrmann et al. 2016; Lauterbach et al. 2017; Wigmann et al. 2019). Similar to the findings of the current study, most authors found differences in the clustering results produced by the two methods. The reason for the occurrence of such differences is the use of data that differ in their degree of variability. HCA creates clusters by calculating distances based on consensus spectra that are an average of several single spectra and do not reflect the variance within samples. In contrast, DAPC separates samples on the basis of the maximum variance found between the single spectra taken from each sample (Kehrmann et al. 2016). DAPC therefore can be used to identify single outliers probably produced by technical variation during sample preparation or during the measurement, which may have an influence on the clustering of the mean spectra used in HCA.

All in all, the clustering of mean spectra using HCA resulted in a clear separation of the reference specimens into a group representing $T$. controversa and a second group representing $T$. caries together with $T$. laevis congruent to the classification by germination behavior. Using DAPC, the 52 reference specimens were separated into four groups, which consisted of $T$. controversa only, T. caries only, T. caries together with T. laevis, and $T$. caries together with $T$. controversa. The highest variation of common mass spectra profiles between the groups was identified when choosing four groups using Bayesian information criterion (BIC) included in DAPC using adegenet 2.0.0 (Jombart and Collins 2015). Three or two groups would have been obvious when 
expecting three different species or two groups representing the causal agents of common bunt and dwarf bunt, respectively, but it seems like there was more variation in the MALDI-TOF MS profiles between the analyzed samples. At first sight, DAPC seemed to be able to distinguish the $T$. caries from the T. laevis specimens in contrast to HCA, but a closer look reveals that no further discrimination between the two species was possible with the applied protocol. The main difference between the DAPC groups comprising T. caries and T. laevis was the origin of the specimens, supporting the hypothesis of regional but not speciesderived clustering. The specimens T. laevis "L" and T. caries "T" originated from the USA and clustered together in contrast to the European T. caries "A" samples. In contrast, no clustering according to geographic origin - USA vs. Europe - could be identified in the specimens used for T. controversa. More samples, especially $T$. laevis specimens from another origin, are needed to further examine the occurrence of species-specific or region-dependent clustering of Tilletia species. All in all, the vast majority of $T$. controversa specimens, except two out of 21, were separated from T. caries and T. laevis by DAPC. In total, the clustering of the 52 reference specimens by HCA was more specific. However, both analysis methods were not able to distinguish the common bunt species T. caries and T. laevis based on mass spectra created by MALDI-TOF MS supporting the clustering obtained by germination behavior and initial results obtained by genome sequencing, which indicated a high degree of genomic identity of T. caries and T. laevis (Sedaghatjoo et al. 2021b, submitted). Several studies already query the common taxonomic classification of the three Tilletia species (Russell and Mills 1994; Carris et al. 2007), especially the separation of $T$. caries and $T$. laevis as two distinct species (Shi et al. 1996). The groupings of specimens obtained by DAPC could also indicate a conspecific status of T. caries and T. laevis. Both agents of the common bunt disease share the same physiological features of teliospores and do not differ in the host range and distribution or their pathology towards wheat (Leppik 1970; Wilcoxson and Saari 1996). Several studies also showed that Tilletia species can hybridize. As a consequence, genetic exchange between species could lead to highly variable morphological characteristics (Holton and Kendrick 1956; Silbernagel 1964) which would also be represented in the variability of the proteome. Moreover, the occurrence of different morphotypes is quite common among microorganisms (Armaleo and Clerc 1991; Gilbert et al. 2018). It has been demonstrated that the presence or absence of a single gene or even few SNPs can suffice to create two or more morphotypes of one species (Gilbert et al. 2018). In addition, also the microenvironment and exogenous factors can influence the morphogenetic characteristics of fungi (Lin et al. 2015). It is currently unknown which genes are responsible for the expression of the morphological characteristics such as shape and height of ornamentation of the cell wall of Tilletia teliospores (Nguyen et al. 2019; Sedaghatjoo et al. 2021b). Since it appears that micromorphological spore characteristics are the only possibility to distinguish the two common bunt species T. caries and T. laevis, we suggest that those two taxa could be treated as two morphotypes of the same species.

\section{Classification of test specimens and accuracy of the MALDI-TOF MS method}

Focusing on the 15 Tilletia spp. test specimens in this study, the main differences between the two analytical methods became obvious with specimens AZH1, AZH2, and L-1. These clustered together $T$. caries and $T$. laevis by DAPC but together with the T. controversa cluster or even as outgroup when analyzed by HCA (see Table 4). Referring to the germination behavior and the morphological identification of specimens AZH1 and AZH2, the results obtained by DAPC appear more reliable. The loss of viability of the L-1 teliospores, depicted by lack of germination, may have caused an effect on the proteome spectra, which became obvious by HCA. Enzymes potentially essential for teliospore germination could be reduced during a lifetime (Schauz 1968). Nonviable Tilletia teliospores compared with viable ones did not show lipase or glucosidase activity and lack acid phosphatase enzymes (Yu et al. 1984; Chastain and King 1990). Talbot et al. (2010) showed that in some cases, MALDI-TOF MS peak information of nonviable samples differ from the representative peaks in spectra of active spores. Such peak variations could be crucial considering the processing of the mass spectra for discrimination of the species by HCA. Creating a consensus spectrum of a nonviable sample may reduce weak signals still detectable by DAPC focusing on the variances. The grouping of specimen L-1 along with the other T. laevis species by DAPC (see Table 3 ) indicates that enough species-specific mass spectra of nonviable samples can be generated by MALDI-TOF MS. Other challenging test samples were specimens AI and D-7. Both were difficult to identify morphologically as reflected by the conflicting determinations of these specimens by the experts. Based on our developed MALDI-TOF MS method, the specimen AI was determined as one of the common bunt species, but identification to species level was impossible. On the other hand, the new MALDI-TOF MS method grouped specimen D-7 as T. controversa in accordance with its germination behavior confirming the potential of MALDI-TOF MS to distinguish Tilletia specimens comprising varying morphological characteristics.

Finally, summing up the potential false classifications by MALDI-TOF MS analysis methods considering the whole set of 67 Tilletia specimens, both HCA and DAPC clustered four specimens incorrectly (AZH1, AZH2, AZH3, L-1 vs. AZH3, D-3, D-4, OA6), while only one specimen (AZH3) remained heterogeneous (see Table 1). Both MALDITOF MS clustering analyses classified this specimen as $T$. 
controversa in contrast to the specific germination behavior and morphological species identification classified it as $T$. caries or T. laevis. Therefore, the newly developed MALDITOF MS method resulted in an accuracy of $98.51 \%$ (Table 5) and hence behaves similar to the germination behavior-based determination, but is much faster. By integrating HCA and DAPC, taking the similarities as well as the variances of the MALDI-TOF MS spectra into account, the best results in discrimination of the studied Tilletia species can be obtained.

In conclusion, in this study, we developed and optimized the MALDI-TOF MS method for the differentiation of three important wheat pathogens applying teliospores isolated from bunt balls, which has proven to be a useful and fast tool. However, T. caries and T. laevis, the causal agents of common bunt, cannot be individually discriminated, but separated from $T$. controversa, the causal agent of dwarf bunt. This supports a potentially conspecific status of T. caries and T. laevis or even two morphotypes of one common species causing identical disease symptoms and sharing the same germination requirements along with a related protein composition, shown in this study. To easily screen new Tilletia specimens or a large number of specimens by MALDI-TOF MS in the future, validated main spectrum profiles (MSP) of each Tilletia species are needed for a fast and specific species identification. These specific MSPs could be produced and deposited in a database like the MSI platform (Normand et al. 2017) for further studies. Our developed MALDI-TOF MS method can be helpful in testing Tilletia bunt balls collected during field inspections, especially with regard to quarantine regulations or for breeding applications.

Supplementary Information The online version contains supplementary material available at https://doi.org/10.1007/s00253-021-11757-2.

Acknowledgements We sincerely thank colleagues who provided sample material for our study. Special thanks to Dr. Peter Büttner, Arno Eberle, Robert Bauer, and Monika Sedlmeier (Bavarian State Research Center for Agriculture, Germany) for supporting the morphological determination of the specimens. The technical assistance of Monika Sedlmeier is gratefully acknowledged. We are grateful to Dr. Maik Hilgarth (Technical University of Munich, Germany) and Dr. Alexander Lauterbach (Enzianbrennerei Grassl, Germany) for their help and advice in bioinformatics as well as to Dr. Évelin Tatsch (née Wigmann) (Technical University of Munich, Germany) and Dr. Melanie Pavlovic (Bavarian Health and Food Safety Authority, Germany) for their advice on preparation of samples for MALDI-TOF MS analyses and for the technical support.

Author contribution M.K.F. conceptualized the study, designed and performed the experiments, analyzed the data, and drafted the manuscript.

S.S. acquired samples, assisted in fungal identification and culture. W.M. assisted in fungal identification and administrated the project. B.K. administrated the project and acquired funding and samples.
L.N. contributed to the conceptualization of the study and acts as the corresponding author.

All authors revised and approved the manuscript.

Funding Open Access funding enabled and organized by Projekt DEAL. The Federal Ministry of Food and Agriculture of the Federal Republic of Germany funded this research project based on a decision of the German parliament (grant numbers 2812NA128 and 2812NA017).

Data availability All specimens analyzed during the current study are stored and are available at the official seed testing laboratory of the Bavarian State Research Center for Agriculture (Freising, Germany) as well as at the Julius Kühn-Institute (JKI) - Federal Research Centre for Cultivated Plants (Braunschweig, Germany). Samples numbered 31-38, 41-47, and 64-69 were supplied by USDA (Agricultural Research Service-U.S. Department of Agriculture) and are available upon request. The mass spectrometry proteomics data are available at the ProteomeXchange Consortium home page under http://proteomece ntral.proteomexchange.org/cgi/GetDataset with the dataset identifier PXD030401.

Code availability Not applicable.

\section{Declarations}

Ethics approval This article does not contain any studies with human participants or animals performed by any of the authors.

Consent to participate Not applicable.

Consent for publication Not applicable.

Competing interests The authors declare no competing interests.

Open Access This article is licensed under a Creative Commons Attribution 4.0 International License, which permits use, sharing, adaptation, distribution and reproduction in any medium or format, as long as you give appropriate credit to the original author(s) and the source, provide a link to the Creative Commons licence, and indicate if changes were made. The images or other third party material in this article are included in the article's Creative Commons licence, unless indicated otherwise in a credit line to the material. If material is not included in the article's Creative Commons licence and your intended use is not permitted by statutory regulation or exceeds the permitted use, you will need to obtain permission directly from the copyright holder. To view a copy of this licence, visit http://creativecommons.org/licenses/by/4.0/.

\section{References}

Armaleo D, Clerc P (1991) Lichen chimeras: DNA analysis suggests that one fungus forms two morphotypes. Exp Mycol 15:1-10. https://doi.org/10.1016/0147-5975(91)90002-U

Banowetz GM, Doss RP (1994) A comparison of polypeptides from teliospores of Tilletia controversa (Kuhn) and Tilletia tritici (Bjerk) Wint. J Phytopathol 140:285-292. https://doi.org/10. 1111/j.1439-0434.1994.tb00610.x

Banowetz GM, Trione EJ, Krygier BB (1984) Immunological comparisons of teliospores of two wheat bunt fungi, Tilletia species, using monoclonal antibodies and antisera. Mycologia 76:51-62. https://doi.org/10.2307/3792835 
Beinhauer J, Raus M, Hanzalová A, Horčička P, Šebela M (2016) Intact spore MALDI-TOF mass spectrometry and proteomic analysis of Puccinia pathogenic fungi. Biochim Biophys Acta - Proteins Proteomics 1864:1093-1103. https://doi.org/10.1016/j.bbapap. 2016.06.002

Bhadauria V, Banniza S, Wang LX, Wei YD, Peng YL (2010) Proteomic studies of phytopathogenic fungi, oomycetes and their interactions with hosts. Eur J Plant Pathol 126:81-95. https://doi. org/10.1007/s10658-009-9521-4

Böhmer M, Colby T, Böhmer C, Bräutigam A, Schmidt J, Bölker M (2007) Proteomic analysis of dimorphic transition in the phytopathogenic fungus Ustilago maydis. Proteomics 7:675-685. https://doi.org/10.1002/pmic.200600900

Bruker Daltonik GmbH (2011) Instructions for use MALDI Biotarget 48. 1-16. www.care-bdal.com

Brun S, Madrid H, Gerrits van den Ende B, Andersen B, MarinachPatrice C, Mazier D, De Hoog GS (2013) Multilocus phylogeny and MALDI-TOF analysis of the plant pathogenic species Alternaria dauci and relatives. Fungal Biol 117:32-40. https://doi.org/ 10.1016/j.funbio.2012.11.003

Büyüköztürk Ş, Çokluk-Bökeoğlu Ö (2008) Discriminant function analysis: concept and application. Egit Arastirmalari - Eurasian J Educ Res 33:73-92

Carris LM, Castlebury LA, Huang G, Alderman SC, Luo J, Bao X (2007) Tilletia vankyi, a new species of reticulate-spored bunt fungus with non-conjugating basidiospores infecting species of Festuca and Lolium. Mycol Res 111:1386-1398. https://doi.org/ 10.1016/j.mycres.2007.09.008

Cassagne C, Ranque S, Normand AC, Fourquet P, Thiebault S, Planard C, Hendrickx M, Piarroux R (2011) Mould routine identification in the clinical laboratory by matrix-assisted laser desorption ionization time-of-flight mass spectrometry. PLoS ONE 6:e28425. https://doi.org/10.1371/journal.pone.0028425

Chalupová J, Sedlářová M, Helmel M, Řehulka P, MarchettiDeschmann M, Allmaier G, Šebela M (2012) MALDI-based intact spore mass spectrometry of downy and powdery mildews. J Mass Spectrom 47:978-986. https://doi.org/10.1002/jms.3046

Chalupová J, Raus M, Sedlárová M, Šebela M (2014) Identification of fungal microorganisms by MALDI-TOF mass spectrometry. Biotechnol Adv 32:230-241. https://doi.org/10.1016/j.biotechadv. 2013.11.002

Chastain TG, King B (1990) A biochemical method for estimating viability of teliospores of $T$. controversa. Physiol Biochem 80:474-476

Chen HY, Chen YC (2005) Characterization of intact Penicillium spores by matrix-assisted laser desorption/ionization mass spectrometry. Rapid Commun Mass Spectrom 19:3564-3568. https:// doi.org/10.1002/rcm.2229

Cunningham JL (1972) A miracle mounting fluid for permanent wholemounts of microfungi. Mycologia 64:906-911

Deutsch E, Bandeira N, Sharma V, Perez-Riverol Y, Carver J, Kundu D, García-Seisdedos D, Jarnuczak A, Hewapathirana S, Pullman B, Wertz J, Sun Z, Kawano S, Okuda S, Watanabe Y, Hermjakob H, MacLean B, MacCoss M, Zhu Y, Ishihama Y, Vizcaíno J (2020) The ProteomeXchange consortium in 2020: enabling 'big data' approaches in proteomics. Nucleic Acids Res 48:D1145-D1152

Durán R, Fischer GW (1961) The genus Tilletia. Durán R, Fischer GW (eds). Washington State University, [Pullman, Wash.], p 138

Eibel P, Wolf GA, Koch E (2005) Detection of Tilletia caries, causal agent of common bunt of wheat, by ELISA and PCR. J Phytopathol 153:297-306. https://doi.org/10.1111/j.1439-0434.2005. 00973.x

EPPO (2021) EPPO Standard PM 1/2(30). EPPO A1 and A2 lists of pests recommended for regulation as quarantine pest. https://www. eppo.int/media/uploaded_images/RESOURCES/eppo_standards/ pm1/pm1-002-30-en_A1A2_2021.pdf
Frank AM, Bandeira N, Shen Z, Tanner S, Briggs SP, Smith RD, Pevzner PA (2008) Clustering millions of tandem mass spectra. J Proteome Res 7:113-122. https://doi.org/10.1021/pr070361e

Gao L, Chen WQ, Liu TG (2010) Development of a SCAR marker by inter-simple sequence repeat for diagnosis of dwarf bunt of wheat and detection of Tilletia controversa Kühn. Folia Microbiol 55:258-264

Gao L, Chen W, Liu T (2011) An ISSR-based approach for the molecular detection and diagnosis of dwarf bunt of wheat, caused by Tilletia controversa Kühn. J Phytopathol 159:155-158. https:// doi.org/10.1111/j.1439-0434.2010.01735.x

Gao L, Yu H, Han W, Gao F (2014) Development of a SCAR marker for molecular detection and diagnosis of Tilletia controversa Kühn, the causal fungus of wheat dwarf bunt. World J Microbiol Biotechnol 30:3185-3195. https://doi.org/10.1007/ s11274-014-1746-5

Gao L, Feng C, Li B, Liu T, Liu B, Chen W (2015) Detection of Tilletia controversa using immunofluorescent monoclonal antibodies. J Appl Microbiol 118:497-505. https://doi.org/10.1111/jam.12703

Gilbert MK, Mack BM, Moore GG, Downey DL, Lebar MD, Joardar V, Losada L, Yu J, Nierman WC, Bhatnagar D (2018) Whole genome comparison of Aspergillus flavus L-morphotype strain NRRL 3357 ( type ) and S-morphotype strain AF70. PLoS ONE 13:e0199169. https://doi.org/10.1371/journal.pone.0199169Editor

Goates BJ (2012) Identification of new pathogenic races of common bunt and dwarf bunt fungi, and evaluation of known races using an expanded set of differential wheat lines. Plant Dis 96:361-369

Goates BJ (1996) Common bunt and dwarf bunt. In: Wilcoxson RD, Saari EE (eds) Bunt and smut diseases of wheat: concepts and methods of disease management. CIMMYT, Mexico, D.F., pp $12-25$

Gruenwald M, Rabenstein A, Remesch M, Kuever J (2015) MALDITOF mass spectrometry fingerprinting: a diagnostic tool to differentiate dematiaceous fungi Stachybotrys chartarum and Stachybotrys chlorohalonata. J Microbiol Methods 115:83-88. https:// doi.org/10.1016/j.mimet.2015.05.025

Hanna WF, Vickery HB, Pucher GW (1932) The isolation of trimethylamine from spores of Tilletia levis, the stinking smut of wheat. J Biol Chem 97:351-358

Hess WM, Trione EJ (1986) Use of electron microscopy to characterize teliospores of Tilletia caries and T. controversa. Plant Dis 70:458-460

Hettick JM, Green BJ, Buskirk AD, Kashon ML, Slaven JE, Janotka E, Blachere FM, Schmechel D, Beezhold DH (2008a) Discrimination of Aspergillus isolates at the species and strain level by matrixassisted laser desorption/ionization time-of-flight mass spectrometry fingerprinting. Anal Biochem 380:276-281. https://doi.org/ 10.1016/j.ab.2008.05.051

Hettick JM, Green BJ, Buskirk AD, Kashon ML, Slaven JE, Janotka E, Blachere FM, Schmechel D, Beezhold DH (2008b) Discrimination of Penicillium isolates by matrix-assisted laser desorption/ionization time-of-flight mass spectrometry fingerprinting. Rapid Commun Mass Spectrom 22:2555-2560. https://doi.org/10.1002/rcm.3649

Hoffmann JA (1982) Bunt of wheat. Plant Dis 66:979-986

Holton CS, Kendrick EL (1956) Problems in the delimitation of species of Tilletia occurring on wheat. Res Stud State Coll Washingt 24:318-325

Holton CS, Hoffmann JA, Duran R (1968) Variation in the smut fungi. Annu Rev Phytopathol 6:213-242

IPPC (2016) ISPM 27. Diagnostic protocols for regulated pests. DP 4: Tilletia indica Mitra. https://www.ippc.int/static/media/files/publi cation/en/2016/01/DP_04_2014_En_2015-12-22_PostCPM10_ InkAmReformatted.pdf

ISTA (1984) Working Sheet No. 53. Triticum aestivum, Tilletia contraversa Kühn, Tilletia caries (DC) Tul., Tilletia foetida (Wallr.) Liro. In: ISTA handbook on seed health testing. International Seed Testing Association, Zurich, pp 1-4 
Jayawardena RS, Hyde KD, Jeewon R, Ghobad-Nejhad M, Wanasinghe DN, Liu NG, Phillips AJL, Oliveira-Filho JRC, da Silva GA, Gibertoni TB, Abeywikrama P, Carris LM, Chethana KWT, Dissanayake AJ, Hongsanan S, Jayasiri SC, McTaggart AR, Perera RH, Phutthacharoen K, Savchenko KG, Shivas RG, Thongklang N, Dong W, Wei DP, Wijayawardena NN, Kang JC (2019) One stop shop II: taxonomic update with molecular phylogeny for important phytopathogenic genera: 26-50 (2019). Fungal Divers 94:41-129. https://doi.org/10.1007/s13225-019-00418-5

Jombart T, Collins C (2015) A tutorial for discriminant analysis of principal components (DAPC) using adegenet 2.0.0. 1-43

Josefsen L, Christiansen SK (2002) PCR as a tool for the early detection and diagnosis of common bunt in wheat, caused by Tilletia tritici. Mycol Res 106:1287-1292

Kawchuk LM, Kim WK, Nielsen J (1988) A comparison of polypeptides from the wheat bunt fungi Tilletia laevis, T. tritici, and $T$. controversa. Can J Bot 66:2367-2376. https://doi.org/10.1139/ b88-321

Kehrmann J, Wessel S, Murali R, Hampel A, Bange FC, Buer J, Mosel F (2016) Principal component analysis of MALDI TOF MS mass spectra separates $M$. abscessus (sensu stricto) from M. massiliense isolates. BMC Microbiol 16:1-7. https://doi.org/10.1186/ s12866-016-0636-4

Kemptner J, Marchetti-Deschmann M, Kubicek CP, Allmaier G (2009) Mixed volume sample preparation method for intact cell mass spectrometry of Fusarium spores. J Mass Spectrom 44:16221624. https://doi.org/10.1002/jms.1669

Kochanová M, Zouhar M, Prokinová E, Ryšánek P (2004) Detection of Tilletia controversa and Tilletia caries in wheat by PCR method. Plant Soil Env 50:75-77

Kussmann M, Nordhoff E, Rahbek-Nielsen H, Haebel S, Rossel-Larsen M, Jakobsen L, Gobom J, Mirgorodskaya E, Kroll-Kristensen A, Palm L, Roepstorff P (1997) Matrix-assisted laser desorption / ionization mass spectrometry sample preparation techniques designed for various peptide and protein. J Mass Spectrom 32:593-601

Lau AF, Drake SK, Calhoun LB, Henderson CM, Zelazny AM (2013) Development of a clinically comprehensive database and a simple procedure for identification of molds from solid media by matrix-assisted laser desorption ionization-time of flight mass spectrometry. J Clin Microbiol 51:828-834. https://doi.org/10. 1128/JCM.02852-12

Lauterbach A, Usbeck JC, Vogel RF (2017) MALDI-TOF MS typing enables the classification of brewing yeasts of the genus Saccharomyces to major beer styles. PLoS ONE 12:1-23

Leppik EE (1970) Gene centers of plants as sources of disease resistance. Annu Rev Phytopathol 8:323-344

Li TY, Liu BH, Chen YC (2000) Characterization of Aspergillus spores by matrix-assisted laser desorption/ionization time-of-flight mass spectrometry. Rapid Commun Mass Spectrom 14:2393-2400. https://doi.org/10.1002/1097-0231(20001230)14:24\%3c2393:: AID-RCM178\%3e3.0.CO;2-9

Li C, Wei X, Gao L, Chen W, Liu T, Liu B (2018) iTRAQ-based proteomic analysis of wheat bunt fungi Tilletia controversa, T. caries, and T. foetida. Curr Microbiol 75:1103-1107. https://doi.org/10. 1007/s00284-018-1490-4

Lin X, Alspaugh JA, Liu H, Harris S (2015) Fungal morphogenesis. Cold Spring Harb Perspect Med 5:1-26

Liu JH, Gao L, Liu TG, Chen WQ (2009) Development of a sequencecharacterized amplified region marker for diagnosis of dwarf bunt of wheat and detection of Tilletia controversa Kühn. Lett Appl Microbiol 49:235-240. https://doi.org/10.1111/j.1472-765X.2009.02645.x

Liu J, Li C, Muhae-Ud-Din G, Liu T, Chen W, Zhang J, Gao L (2020) Development of the droplet digital PCR to detect the teliospores of Tilletia controversa Kühn in the soil with greatly enhanced sensitivity. Front Microbiol 11:1-9. https://doi.org/10.3389/fmicb. 2020.00004

Lowther CV (1950) Chlamydospore germination in physiologic races of Tilletia caries and Tilletia foetida. Phytopathology 40:590-603

Luethy PM, Zelazny AM (2018) Rapid one-step extraction method for the identification of molds using MALDI-TOF MS. Diagn Microbiol Infect Dis 91:130-135. https://doi.org/10.1016/j.physb eh.2017.03.040

Mantini D, Petrucci F, Pieragostino D, Del Boccio P, Sacchetta P, Candiano G, Ghiggeri GM, Lugaresi A, Federici G, Di Ilio C, Urbani A (2010) A computational platform for MALDI-TOF mass spectrometry data: application to serum and plasma samples. J Proteomics 73:562-570. https://doi.org/10.1016/j.jprot.2009.11.004

Meiners JP, Waldher JT (1959) Factors affecting spore germination of twelve species of Tilletia from cereals and grasses. Phytopathology 49:724-728

Mulholland V, McEwan M (2000) PCR-based diagnostics of Microdochium nivale and Tilletia tritici infecting winter wheat seeds*. OEPP/EPPO Bull 30:543-547

Nguyen HDT, Sultana T, Kesanakurti P, Hambleton S (2019) Genome sequencing and comparison of five Tilletia species to identify candidate genes for the detection of regulated species infecting wheat. IMA Fungus 10:1-17

Normand AC, Becker P, Gabriel F, Cassagne C, Accoceberry I, GariToussaint M, Hasseine L, De Geyter D, Pierard D, Surmont I, Djenad F, Donnadieu JL, Piarroux M, Ranque S, Hendrickx M, Piarroux R (2017) Online identification of fungi using MALDITOF mass spectrometry: validation of a new web application. J Clin Microbiol 55:2661-2670. https://doi.org/10.1128/JCM. 00263-17

Pandey V, Singh M, Pandey D, Marla S, Kumar A (2018) Secretome analysis identifies potential pathogenicity/virulence factors of Tilletia indica, a quarantined fungal pathogen inciting karnal bunt disease in wheat. Proteomics 18:1-11. https://doi.org/10.1002/ pmic. 201700473

Pandey V, Gupta AK, Singh M, Pandey D, Kumar A (2019) Complementary proteomics, genomics approaches identifies potential pathogenicity/virulence factors in Tilletia indica induced under the influence of host factor. Sci Rep 9:1-15. https://doi.org/10. 1038/s41598-018-37810-1

Perez-Riverol Y, Csordas A, Bai J, Bernal-Llinares M, Hewapathirana S, Kundu D, Inuganti A, Griss J, Mayer G, Eisenacher M, Pérez E, Uszkoreit J, Pfeuffer J, Sachsenberg T, Yilmaz S, Tiwary S, Cox J, Audain E, Walzer M, Jarnuczak A, Ternent T, Brazma A, Vizcaíno J (2019) The PRIDE database and related tools and resources in 2019: improving support for quantification data. Nucleic Acids Res 47:D442-D450

Peterson GL, Whitaker TB, Stefanski RJ, Podleckis EV, Phillips JG, Wu JS, Martinez WH (2009) A risk assessment model for importation of United States milling wheat containing Tilletia contraversa. Plant Dis 93:560-573. https://doi.org/10.1094/ PDIS-93-6-0560

Pieczul K, Perek A, Kubiak K (2018) Detection of Tilletia caries, Tilletia laevis and Tilletia controversa wheat grain contamination using loop-mediated isothermal DNA amplification (LAMP). J Microbiol Methods 154:141-146

Piepenbring M (2009) Diversity, ecology, and systematics of smut fungi. In: Del Claro K, Oliveira PS, Rico-Gray V (eds) Tropical biology and conservation management. EOLSS Publications, Paris, France, pp 141-171

Russell BW, Mills D (1994) Morphological, physiological, and genetic evidence in support of a conspecific status for Tilletia caries, $T$. controversa, and T. foetida. Phytopathology 84:576-582

Schauz K (1968) Die Steuerung der Brandsporenkeimung und Sporidienbildung bei Tilletia caries ( DC ) Tul. durch Licht. Arch Mikrobiol 60:111-123 
Schott AS, Behr J, Quinn J, Vogel RF (2016) MALDI-TOF mass spectrometry enables a comprehensive and fast analysis of dynamics and qualities of stress responses of Lactobacillus paracasei subsp. paracasei F19. PLoS ONE 11:1-23. https://doi.org/10.1371/journ al.pone. 0165504

Sedaghatjoo S, Forster MK, Niessen L, Karlovsky P, Killermann B, Maier W (2021a) Development of a loop - mediated isothermal amplification assay for the detection of Tilletia controversa based on genome comparison. Sci Rep 11:1-13. https://doi.org/10.1038/ s41598-021-91098-2

Sedaghatjoo S, Mishra B, Forster MK, Becker Y, Keilwagen J, Killermann B, Thines M, Karlovsky P, Maier W (2021b) In silico investigations reveal low levels of inter- and intraspecies variation in genome sequences of Tilletia caries, $T$. controversa and T. laevis, causal agents of wheat bunt. Manuscript submitted for publication

Shi YL, Loomis P, Christian D, Carris LM, Leung H (1996) Analysis of the generic relationships among the wheat bunt fungi using RAPD and ribosomal DNA markers. Phytopathology 86:311-318

Silbernagel MJ (1964) Compatibility between Tilletia caries and T. controversa. Phytopathology 54:1117-1120

Sneath PH., Sokal RR (1973) Numerical taxonomy. The principles and practice of numerical classification. Kennedy D, Park RB (eds). W.H.Freeman \& Co Ltd, San Francisco, p 573

Strickert M, Teichmann S, Sreenivasulu N, Seiffert U (2005) Highthroughput multi-dimensional scaling (HiT-MDS) for cDNAarray expression data. In: Duch W, Kacprzyk J, Oja E, Zadrozny S (eds) ICANN 2005. Springer-Verlag, Berlin Heidelberg, Warsaw, Poland, pp 625-633

Sulc M, Peslova K, Zabka M, Hajduch M, Havlicek V (2009) Biomarkers of Aspergillus spores: Strain typing and protein identification. Int J Mass Spectrom 280:162-168. https://doi.org/10.1016/j.ijms. 2008.08.012

Talbot SR, Russmann H, Köhne S, Niederwöhrmeier B, Grote G, Scheper T (2010) Effects of inactivation methods on the analyses of Bacillus atrophaeus endospores using real-time PCR and MALDI-TOF-MS. Eng Life Sci 10:109-120. https://doi.org/10. 1002/elsc.200800078

Taskova RM, Zorn H, Krings U, Bouws H, Berger RG (2006) A comparison of cell wall disruption techniques for the isolation of intracellular metabolites from Pleurotus and Lepista sp. Zeitschrift Fur Naturforsch - Sect C J Biosci 61:347-350. https://doi.org/10. 1515/znc-2006-5-608

Trione EJ (1964) Isolation and in vitro culture of the wheat bunt fungi Tilletia caries and T. controversa. Phytopathology 54:592-596

Trione EJ, Krygier BB (1977) New tests to distinguish teliospores of Tilletia controversa, the dwarf bunt fungus, from spores of other Tilletia species. Phytopathology 67:1166-1172

Usbeck JC, Kern CC, Vogel RF, Behr J (2013) Optimization of experimental and modelling parameters for the differentiation of beverage spoiling yeasts by matrix-assisted-laser-desorption/ ionization-time-of-flight mass spectrometry (MALDI-TOF MS) in response to varying growth conditions. Food Microbiol 36:379_ 387. https://doi.org/10.1016/j.fm.2013.07.004

Usbeck JC, Wilde C, Bertrand D, Behr J, Vogel RF (2014) Wine yeast typing by MALDI-TOF MS. Appl Microbiol Biotechnol 98:37373752. https://doi.org/10.1007/s00253-014-5586-X

Vánky K (2012) Smut fungi of the world. Vánky K (ed). APS Press, St. Paul, Minn., p 1458

Wang X, Zhu W, Pradhan K, Ji C, Ma Y, Semmes OJ, Glimm J, Mitchell J (2006) Feature extraction in the analysis of proteomic mass spectra. Proteomics 6:2095-2100. https://doi.org/10.1002/pmic. 200500459

Weber G, Schauz K (1985) Characterization of spore protein patterns in Tilletia controversa and Tilletia caries with gel electrophoretic methods. J Plant Dis Prot 92:600-605

Welham KJ, Domin MA, Scannell DE, Cohen E, Ashton DS (1998) The characterization of micro-organisms by matrix-assisted laser desorption / ionization time-of-flight mass spectrometry. Rapid Commun Mass Spectrom 12:176-180. https://doi.org/10.1002/ (SICI)1097-0231(19980227)12

Welham KJ, Domin MA, Johnson K, Jones L, Ashton DS (2000) Characterization of fungal spores by laser desorption/ionization time-of-flight mass spectrometry. Rapid Commun Mass Spectrom 14:307-310. https://doi.org/10.1002/(SICI)1097-0231(20000315) 14:5\%3c307::AID-RCM823\%3e3.0.CO;2-3

Wieser A, Schneider L, Jung J, Schubert S (2012) MALDI-TOF MS in microbiological diagnostics - identification of microorganisms and beyond (mini review). Appl Microbiol Biotechnol 93:965974. https://doi.org/10.1007/s00253-011-3783-4

Wigmann ÉF, Behr J, Vogel RF, Niessen L (2019) MALDI-TOF MS fingerprinting for identification and differentiation of species within the Fusarium fujikuroi species complex. Appl Microbiol Biotechnol 103:5323-5337. 103:5323-5337

Wilcoxson RD, Saari EE (1996) Bunt and smut diseases of wheat: concepts and methods of disease management. Wilcoxson, R.D. Saari, E.E. (eds). CIMMYT, Veracruz, Mexico, D.F., p 66

Yu SQ, Trione EJ, Ching TM (1984) Biochemical determination of the viability of fungal spores and hyphae. Mycologia 76:608-613

Zhang H, Huang W, Qiu Z, Shi Q, Wang X, Wu Y (2007) Primary study on application of ELISA and PCR to research of Tilletia contraversa. J Xinjiang Agric Univ 30:88-90

Zouhar M, Mazáková J, Prokinová E, Váňová M, Ryšánek P (2010) Quantification of Tilletia caries and Tilletia controversa mycelium in wheat apical meristem by real-time PCR. Plant Prot Sci 46:107-115

Publisher's note Springer Nature remains neutral with regard to jurisdictional claims in published maps and institutional affiliations. 